\title{
THE VIOLETS OF THE BRAZILIAN SAVANNA: A REVISION OF THE POMBALIA LANATA COMPLEX (VIOLACEAE), WITH DESCRIPTIONS OF TWO NEW SPECIES
}

\begin{abstract}
J. Paula-Souza' ${ }^{1}$ A. G. Lima ${ }^{2,3}$ \& V. C. Souza ${ }^{2}$
Pombalia Vand. (Violaceae) is represented in the Cerrado by a well-supported monophyletic group of species known as the Pombalia lanata complex, characterised by some unique vegetative and reproductive features within the genus. This group includes six species - Pombalia cristalina, $P$. insignis, $P$. lanata, $P$. poaya, $P$. strigoides and $P$. velutina - the first two of which are new to science. Pombalia lanata shows the widest geographical distribution throughout the Central Brazilian Plateau and the Espinhaço Range in Minas Gerais state, with a disjunction in Misiones Province, Argentina. Because most species in this group are narrow endemics, we evaluated the conservation status of all taxa. An identification key for the species, descriptions, illustrations, maps of geographical distribution and nomenclatural notes are also provided.
\end{abstract}

Keywords. Cerrado, disjunct distribution, endangered species, endemism, Hybanthus, new species, taxonomy.

Received 2 March 2020 Accepted 20 November 2020 Published 07 April 2021

\section{Introduction}

The genus Pombalia Vand. (Violaceae) comprises 42 species distributed throughout the Americas (Paula-Souza \& Ballard, 2014; Paula-Souza \& Souza, 2015). Half of these species are found in Brazil, and in this country the Cerrado (the Brazilian savanna), with 13 taxa, is the richest phytogeographical domain in terms of number of species of the genus (PaulaSouza, 2018).

The savannas of the Central Brazilian Plateau are also home to a morphologically well-defined group of species called the Pombalia lanata complex, which takes its name from its most common and widely distributed species. The complex is characterised by two unique features within the genus: anthers ornamented with reduced, hyaline connective appendages (except Pombalia insignis Paula-Souza; see discussion below) and a well-developed, bud-bearing underground root-like system. Preliminary phylogenetic studies have resolved a clade of six species corresponding to the Pombalia lanata complex (Paula-Souza, 2009). Five of these species occur in the Brazilian Cerrado [P. cristalina Paula-Souza, P. insignis,

${ }^{1}$ Departamento de Botânica, Universidade Federal de Santa Catarina, Rua Eng. Agronômico Andrei Cristian Ferreira 216, 88040-535 Florianópolis - SC, Brazil. E-mail: j.paula.souza@ufsc.br.

2 Departamento de Ciências Biológicas, Universidade de São Paulo/ESALQ, Avenida Pádua Dias 11, CP 09, 13418-900 Piracicaba - SP, Brazil.

${ }^{3}$ Escola Nacional de Botânica Tropical, Jardim Botânico do Rio de Janeiro, Rua Pacheco Leão 2040, 22460-030 Rio de Janeiro - RJ, Brazil. 
P. lanata (A.St.-Hil.) Paula-Souza, P. poaya (A.St.-Hil.) Paula-Souza and P. strigoides (Taub.) Paula-Souza], and the sixth species, Pombalia velutina (Schulze-Menz) Paula-Souza, has the southernmost distribution of the group (from southern São Paulo state in Brazil to Paraguay).

Taxonomic circumscriptions within the Pombalia lanata complex have presented difficulties, with species delimited mainly by differences in the indumentum, size of the leaves, and a few conserved traits of floral structure. These circumscriptions have resulted in unreliable identification of specimens and the description of unnecessary names, and have hindered the recognition of new taxa within the complex. Therefore, we searched for patterns corresponding to the extremes of morphological variation, with the aim of accurately circumscribing the members of the Pombalia lanata complex, and in the course of our work detected two previously undescribed taxa. Here, we present an identification key for the six species belonging to the Pombalia lanata complex, along with morphological descriptions, distribution maps, illustrations and assessments of their conservation status.

\section{Materials and methods}

This work was based on field observations of living specimens, consultation of pertinent literature, and information from herbaria of the Americas and Europe, obtained through visits and loans of specimens (acronyms according to Thiers, continuously updated): $A, A L C B, B$, BHCB, BHO, BM, BR, CEN, CEPEC, CESJ, COR, CTES, CUVC, CVRD, E, ESA, F, FUEL, G, GFJP, GH, GUA, H, HAS, HB, HBG, HEPH, HMS, HRB, HRCB, HUA, HUCS, HUEFS, IAC, IAN, IBGE, ICN, INPA, IPA, K, LP, M, MAC, MBM, MBML, MEXU, MG, MO, NY, OUPR, P, PACA, PEL, R, RB, SI, SMDB, SP, SPF, SPSF, U, UB, UEC, UFG, ULM, UPCB, US, VIES, W, WU and XAL. Phenology data were obtained from herbarium specimens.

The species' conservation status was evaluated according to IUCN (2012). Area of occupancy (AOO) and extent of occurrence (EOO) were calculated using the software GeoCAT and the IUCN default cell width of $2 \mathrm{~km}$ (Bachman et al., 2011). Species whose EOO are indicated as not measurable did not reach the minimum $4 \mathrm{~km}^{2}$ of the default cell and were therefore evaluated under the AOO parameters of Critically Endangered species (less than $10 \mathrm{~km}^{2}$ ).

\section{Results and discussion}

\section{Floral morphology and pollination biology}

Of the six species in the Pombalia lanata complex, the most widely distributed and most variable morphologically is Pombalia lanata, for which the complex is named. This species shows a broad range of variation in leaf shape and size and indument type across its distribution from the northern Brazilian Plateau through the San Ignacio region in Misiones province, Argentina (Paula-Souza et al., 2011). Pombalia lanata thus occurs sympatrically with all the remaining species of this group except for $P$. velutina. The absence of spatial 
isolation and their synchronous phenology could favour the formation of hybrid populations, characterised by the intermediate morphological forms between their putative parents. Indeed, intermediate forms growing in the same areas as well-defined morphotypes were detected on several occasions during our fieldwork, and these involved all species of the Pombalia lanata complex that occurred sympatrically, including, for example, at Chapada dos Veadeiros, Goiás state, where the endemic $P$. strigoides co-occurs with $P$. lanata and $P$. poaya. Although hybridisation among the tropical taxa of Violaceae is still poorly investigated, this is a frequent and well-documented phenomenon within the largest genus of the family, Viola L., whose rapid speciation in temperate or high-altitude tropical areas might have been favoured by interspecific hybridisation combined with genome duplications (allopolyploidy) (Marcussen et al., 2012, 2014). This subject was addressed by Nunes et al. (2006) in the only study available to date for Pombalia, testing the hybridisation between two closely related species, $P$. arenaria (Ule) Paula-Souza and $P$. calceolaria (L.) Paula-Souza, which have emerged as successive sister groups of the Pombalia lanata complex, based on the results of recent phylogenetic analyses (Paula-Souza, 2009). Nunes and colleagues found no diagnostic loci that would have enabled confirmation of natural hybridisation; however, additional genetic analyses have indicated the introgression of Pombalia arenaria genes to $P$. calceolaria (Nunes et al., 2006), and the possibility of formation of hybrids has been further reinforced by morphometric analyses, suggesting that the phenomenon might also occur among tropical taxa of the family (Nunes et al., 2006).

Floral features are evolutionarily labile in the Violaceae, as inferred from phylogenetic analyses that overturned the traditional division of groups based on floral symmetry (Hekking, 1988; Wahlert et al., 2014). The segregation of Hybanthus sensu lato into at least seven distinct hybanthoid lineages is an example of how strongly zygomorphic flowers and their associated androecium morphologies evolved independently throughout the history of the family. Therefore, it is not surprising to find shifts in the morphology of connective appendages, such as the reversion to large, orange-brown projections - typical of most Pombalia species - in Pombalia insignis (Figure 4C) and to an intermediate form of large, hyaline projections, as seen in $P$. strigoides (Figures 9C, 10E). In contrast, the character of reduced, hyaline projections well known in the Pombalia lanata complex is also shifted in the unrelated $P$. graminifolia (Chodat) Paula-Souza.

Likewise, petal colour is a variable feature for some species of Pombalia, including for the two most widely distributed and frequent species of the Cerrado: $P$. lanata and $P$. poaya. The petals of these two species display all shades between white and purplish blue, but still, always with the bright yellow or white spot at the base of the anterior petal that is found in nearly all hybanthoid species (Figure 5). We observed that the more geographically isolated a species was, the less variable was its corolla colour. Thus, Pombalia cristalina and $P$. velutina consistently had white-creamy petals (Figure $2 \mathrm{~A}, \mathrm{~B}$ and Figure $9 \mathrm{~F}$, respectively), and $P$. insignis and $P$. strigoides were described as having different shades of blue petals 
(rarely white in the latter), yet all bearing the same basal yellow or white spot (Figure 2E and Figure 9A-D, respectively).

Investigations of reproductive biology in tropical taxa of the Violaceae are scarce, but authors of the few studies carried out with species of Hybanthus sensu lato (Augspurger, 1980, and Rosero-Lasprilla, 1997, with Pombalia; Munzinger \& Pauly, 2003, with Afrohybanthus) reported similar pollination mechanisms to those observed in the widely studied Viola (Beattie, 1969, 1971; Freitas \& Sazima, 2003), possibly constituting a pattern throughout the strongly zygomorphic-flowered taxa, given their overall similar floral architecture. In these groups (and the weakly zygomorphic-flowered Rinorea sensu lato), the androecium shows an elaborate morphology that prevents the possibility of self-pollination in self-compatible species; this mostly involves subsessile, introrse anthers that are longitudinally fused around the ovary through numerous papillae, and the anthers' connective apically furnished with large membranous projections that are imbricate to form a cone around the style (Figure 6G).

The tubular structure formed by the imbricate membranous appendages efficiently encloses the released pollen grains; therefore, although the species are generally self-compatible, an external agent is required for pollination to be accomplished. Changes in the relative positions of the stigmatic opening and the connective appendages, in response to the visitors' movements, are essential for pollination success, and in their attempts to access pollen grains, the insects sometimes engage in specialised behaviours such as buzz pollination (Roubik, 1992; Freitas \& Sazima, 2003).

The species of the Pombalia lanata complex, however, exhibit two significant modifications in this general morphological pattern that suggest loss of the mechanism that prevents the easy release of pollen, thus allowing not only self-pollination (although compatibility is entirely unknown in this group), but also, more importantly, pollen access to generalist visitors. First is elevation of the anthers on slender and long filaments, thus exposing the base of ovary where the released pollen grains accumulate, a feature that is also found in a few species of Pombalia, including their hybridising sister groups $P$. arenaria and $P$. calceolaria. Second, and exclusive to the Pombalia lanata complex (except $P$. insignis and the unrelated $P$. graminifolia), is reduction of the anthers' apical connective appendages, such that the typical conical structure around the style is not formed (Figure 6F).

Bees and wasps are the most frequent pollinators reported for the strongly zygomorphicflowered genera of Violaceae, particularly small, solitary bees and the eusocial stingless bees (Apidae: Meliponini). The latter are of special interest in our context, because they are the most generalist in their use of floral resources in the Neotropics (Pacheco Filho et al., 2015) and the Brazilian savanna is a hotspot for this group of bees (Pioker-Hara et al., 2014). The same aspects that make the Meliponini such a relevant group in maintaining genetic variability in remnant fragments of the Cerrado flora, namely large colonies of polylect insects consisting of numerous workers gathering resources (Michener, 1979), combined 
with the drastic morphological shifts of the androecium observed in this group, might favour the formation of hybrids within the Pombalia lanata complex. In a broader context, this association might have contributed to the occupation of open habitats by members of this clade, from elements typical of forested areas [e.g. Pombalia brevicaulis (Mart.) PaulaSouza and $P$. heterosepala (Eichler) Paula-Souza] or the Caatinga seasonally dry woodlands (P. arenaria), to the widespread $P$. calceolaria or those showing adaptations to the climatic and edaphic conditions of the Cerrado (discussed below) that are unique in the group.

\section{Underground root-like system}

Fire damage to and information on the labels accompanying herbarium specimens from species of the Pombalia lanata complex suggest that collections were mostly made soon after a wildfire, sometimes as recently as a month after the disturbance. Formation of a well-developed, bud-bearing underground root-like system is a common plant survival strategy; in the Pombalia lanata species complex, it has presumably evolved in response to the recurrent fires in the Cerrado and as an adaptation to the strongly seasonal climate and edaphic conditions of deep, acidic, well-drained soils with high aluminum content (Filgueiras, 2002; Alonso \& Machado, 2007; Appezzato-da-Glória \& Cury, 2011; February et al., 2020). $A$ bud-bearing underground system ensures regrowth after fire events and enhances water absorption in deeper soil layers during the dry months.

Ongoing anatomical studies will allow better characterisation of the underground root-like systems in the Pombalia lanata complex. Preliminary examination of several herbarium specimens that were collected with the upper portion of subterranean tissues show a thickened and prolifically bud-bearing structure, just below ground level, from which the shoots originate after fire (Figure $8 \mathrm{~A}$ ). This thickening is followed by a cylindrical axial root of 5-10 $\mathrm{mm}$ in diameter, and field observations have shown that this primary root in Pombalia lanata has orthotropic growth and is flexible, reaching more than $50 \mathrm{~cm}$ in depth. It is noteworthy that the underground parts of Pombalia velutina (Figure $9 \mathrm{E}$ ) are not as thick and developed as in the remaining species that occur in the core area of the Cerrado, a difference that might be associated with the species' distribution in peripheral areas (southern São Paulo state in Brazil to Paraguay) that are not subject to fire regimes and edaphic restrictions like those of the Central Brazilian savanna.

The only specialised root system in Violaceae besides that of the Pombalia lanata complex was reported for Paypayrola arenacea, a dwarf species of an unrelated woody group of the family growing in scrubby savannas of Venezuela (Aymard et al., 2014). The Amazonian oligotrophic white sand savannas of northern South America are floristically and ecologically distinct from the Central Brazilian Cerrado (Eiten, 1972; Lenthall et al., 1999), and no species of the Pombalia lanata complex have been recorded in this phytogeographical zone of the South American savanna. 


\section{Indument}

The indument, when associated with androecium morphology, is a useful feature with which to distinguish the species within the Pombalia lanata complex. Despite the considerable amount of variation in this character, it is possible to recognise three patterns of indument and their associated trichome types.

- Spreading-villous. Exclusive to Pombalia poaya, this indument is readily recognised by its simple, long, soft and spreading trichomes covering the entire plant body (Figure 5E).

- Strigose. This indument is observed in Pombalia cristalina and P. strigoides and is composed of simple and stiff trichomes that are adpressed to the organs (Figures 1C, 9D). The indument is overall densely distributed throughout the plant body, except on the leaves of Pombalia cristalina, in which the trichomes are restricted to the basal parts, becoming increasingly sparse upwards along the midrib (Figure $2 A, B, D$ ).

- Tomentose-velutinous with stellate trichomes. This is the pattern for Pombalia insignis, $P$. lanata and $P$. velutina, and in its typical form is displayed as a dense indument of 5-9 simple, tufted trichomes (Figures 1A,E, 5C, 9G), the grouped hairs thus forming a stellate trichome (sensu Webster et al., 1996; Inamdar \& Gangadhara, 2008). Some populations display a sparser indument, and in such cases the hairs on the leaves are so scattered as to not form the typical stellate structures, or they are grouped in poorly elaborated units (Figure 1B; additional illustrations in Paula-Souza \& Ballard, 2014). Although the stellate trichomes on the leaves can vary in number of radii within a single individual, and very frequently are all distributed as ungrouped, single hairs, the typical stellate structure in a dense indument is always found in floral parts (e.g. sepals and ovary), possibly as a strategy to protect against predation or heat loss.

Plant species in alpine tropical systems often have indument, which provides protection against frosts (Hedberg, 1964), ultraviolet radiation (Karabourniotis \& Bornman, 2002), and the loss of water (Ehleringer \& Björkman, 1978; Ehleringer, 1982) and heat (higher floral temperatures are associated with significantly increased seed production; Miller, 1986). In this context, the development of a dense indument in the Pombalia lanata complex could be related to the occupation of colder habitats, as has been hypothesised for the lianescent lineage of Violaceae extending to the Andean highlands (Paula-Souza \& Pirani, 2014). The stellate trichomes in this family are found exclusively in the Pombalia lanata complex and its sister group, $P$. arenaria. Although the indument is equally variable across the wide distribution of Pombalia arenaria in northeastern Brazil, it has been observed that its typical morphotypes - densely velutinous with multibranched stellate hairs - are found mostly in the highlands of the Chapada Diamantina. The morphotypes of Pombalia arenaria at lower elevations tend to display a much sparser indument of single or few-branched stellate hairs, and these are areas where its simple-haired sister lineage $P$. calceolaria becomes more abundant than in the highlands, also occurring in sand dunes at sea level, where the former species is absent. 


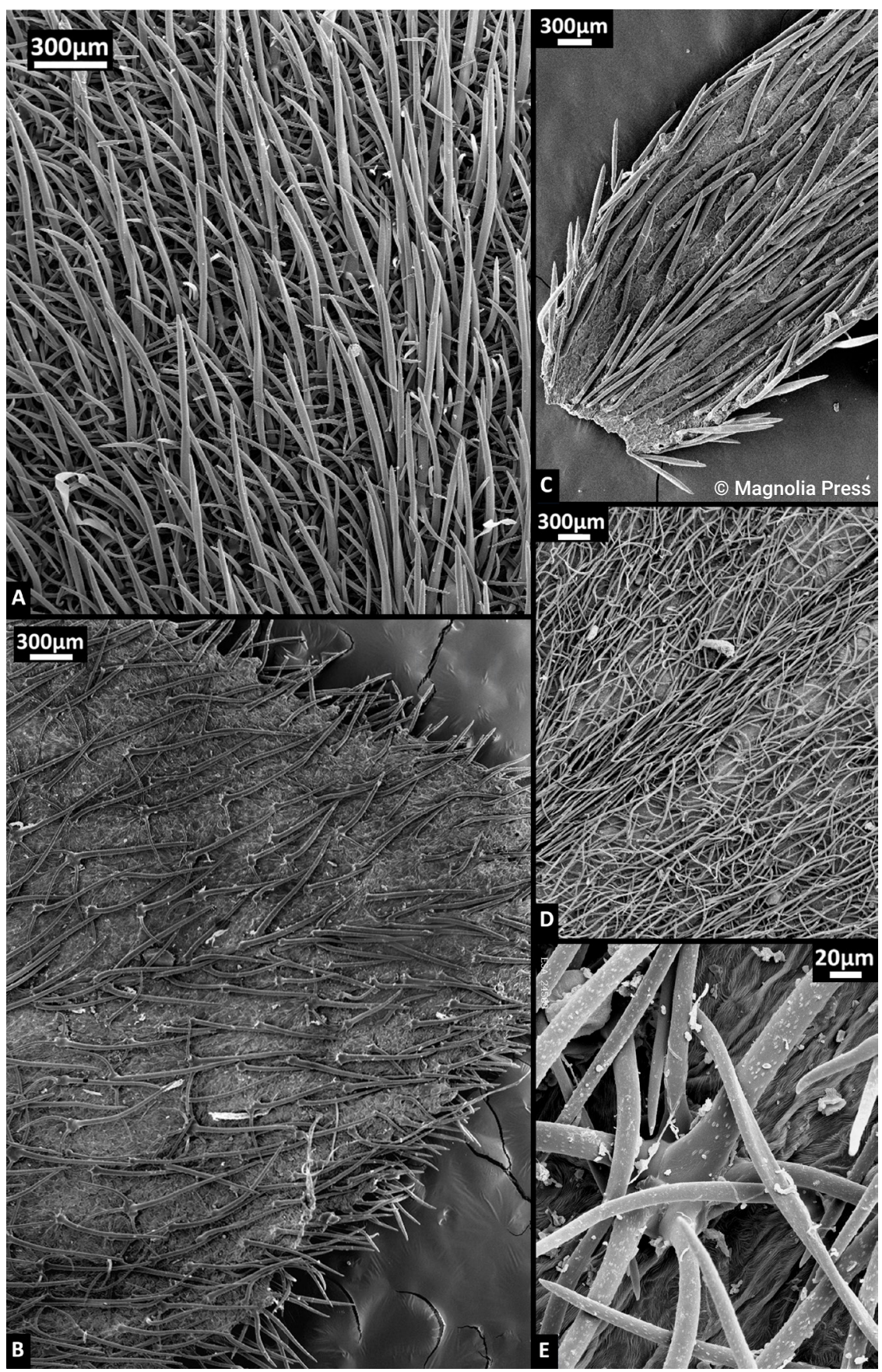

Figure 1. Scanning electromicroscopic images of the indument in species of the Pombalia lanata complex: A and B, Pombalia lanata; C, P. strigoides (from Paula-Souza \& Ballard Jr., 2014, and reproduced with the permission of the copyright holder, Magnolia Press); D and E, P. velutina. 
Unfortunately, the only available (yet still unpublished) phylogeny including the Pombalia lanata complex (Paula-Souza, 2009) lacks sufficient resolution to provide a definitive picture of the evolution of indument among its species. However, the same mechanism that favoured the occupation of new habitats in the lianescent Violaceae and Pombalia arenaria might also be inferred for the Cerrado group in areas of lower temperatures where a denser indument might confer some adaptive advantage. The broad, fimbriate sepals and denser coating on the congested inflorescences of Pombalia velutina (Figure $9 \mathrm{~F}, \mathbf{G}$ ) might additionally play an important role in maintaining warmer temperatures inside the flowers (Miller, 1986; Yang et al., 2008), thus contributing to the occurrence of this species in more southern areas of the group's distribution, which are prone to colder temperatures.

\section{Taxonomic treatment}

\section{Key to species of the Pombalia lanata complex}

1a. Flowers most frequently arranged in congested terminal inflorescences, or sometimes in poorly defined racemose inflorescences; sepals fimbriate 6. P. velutina

1b. Flowers solitary, axillary; sepals entire 2

2a. Anterior petal $>20 \mathrm{~mm}$ long; connective appendage orange-brown 2. P. insignis

2b. Anterior petal $<20 \mathrm{~mm}$ long; connective appendage hyaline 3

3a. Stems and leaves strigose 4

3b. Stems and leaves velutinous, villous or spreading-villous 5

4a. Leaves 10-14 × 3-4.4 mm, connective appendages c. $0.3 \mathrm{~mm}$ long 1. P. cristalina

4b. Leaves 4-7.9 × 1.5-3 mm; connective appendages 1-1.2 mm long 5. P. strigoides

5a. Stems and leaves villous-spreading, the hairs simple 4. P. poaya

5b. Stems and leaves tomentose to densely villous, less frequently pubescent, the hairs never spreading and usually grouped in tufts (stellate)

3. P. lanata

1. Pombalia cristalina Paula-Souza, sp. nov.

Pombalia cristalina is morphologically similar to $P$. strigoides (Taub.) Paula-Souza but is distinguished by its larger leaves 10-14 × 3-4.4 mm (versus 4-7.9 × 1.5-3 mm), smaller, c. $0.3 \mathrm{~mm}$ long connective appendages (versus 1-1.2 mm long) and white or creamy petals (versus purple, blue or lilac, rarely white). - Type: Brazil, Goiás, Cristalina, estrada para Unaí, c.600 m da BR 040, cerrado degradado com campo rupestre adjacente, $16.7453^{\circ} \mathrm{S}, 47.6047^{\circ} \mathrm{W}$ [16 $\left.16^{\circ} 44^{\prime} 43.1^{\prime \prime S}, 47^{\circ} 36^{\prime} 16.9^{\prime \prime} \mathrm{W}\right], 1230 \mathrm{~m}$ a.s.l., 18 x 2006, J. PaulaSouza, G.O. Romão \& G.S. Leite 8611/6768 (holotype SPF [SPF182079], isotype ESA [ESA97122]). Figures 2A-D, 10F. 


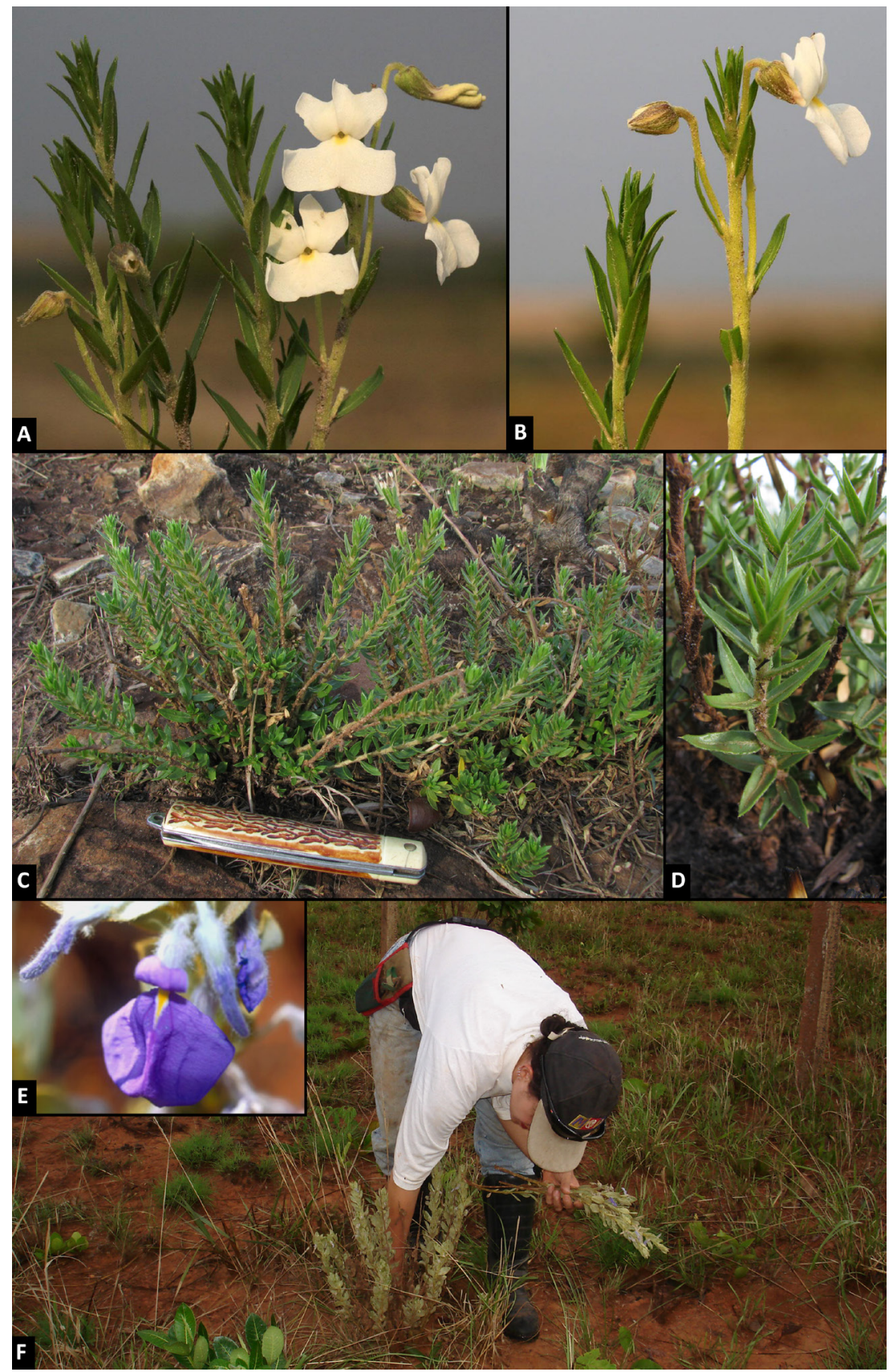

Figure 2. A-D, Pombalia cristalina Paula-Souza, sp. nov.: A and B, flowering branches; C, habit; D, detail of vegetative branch. E and F, Pombalia insignis Paula-Souza, sp. nov.: E, flower; F, habit and type locality. Photographs: A and B, Henrique Moreira; C and D, Juliana de Paula-Souza; E, Marco Batalha; F, Gérson de Oliveira Romão. 
Suffrutescent herb, 10-15 $\mathrm{cm}$ high, branched from a well-developed, bud-bearing underground root-like system, erect; stems densely strigose, internodes 4-14 mm. Stipule $2-3 \times$ c. $0.5 \mathrm{~mm}$, narrowly elliptic, margin entire, hyaline and inconspicuous among the dense indument; leaves alternate, sessile; blade 10-14 × 3-4.4 mm, narrowly oblong, narrowly elliptic or narrowly lanceolate, apex acuminate, margin entire, base truncate, 1-nerved, densely strigose along the nerve especially at the base. Flowers white or creamy, with a yellow spot at the base of the anterior petal, solitary, axillary; pedicel $1-1.7 \mathrm{~cm}$ long, strigose; bracteoles 2-2.5 × c.0.25 mm, linear; sepals slightly unequal, 3.5-5.8 $\times$ 1-1.3 mm, lanceolate, subfalcate, apex acuminate, margin entire, base truncate, densely strigose; posterior petals $5-5.8 \times 1.7-2.1 \mathrm{~mm}$, oblong to lanceolate, subfalcate, apex round; lateral petals $8.2-13.1 \times 4.2-7.5 \mathrm{~mm}$, falcate, clawed, the blade obtriangular, apex truncate or emarginate, villous beneath; anterior petal 13-15 $\times 6.7-18 \mathrm{~mm}$, including a claw 5.5-6.5 mm long, transversely oblong, apex emarginate or less frequently truncate, base truncate or less frequently obtuse, villous; filaments $0.8-1.5 \mathrm{~mm}$ long, anthers $1.15-1.35 \mathrm{~mm}$ long, connective appendages hyaline, c. $0.3 \mathrm{~mm}$ long, apex round or apiculate, asymmetrical, the 2 anterior stamens each bearing a noduliform gland at the base of the anthers or in the middle of the filament, sometimes the gland inconspicuous corresponding to a swollen area, villous; style 3-3.5 mm long, glabrous, ovary 1.15-1.3 mm long, strigose, ovules 12(13). Capsule 7.5-8.5 × c.7 mm, ovoid or ellipsoid; seeds not seen.

Etymology. The epithet refers to the municipality of Cristalina, where the new species is found. In addition to being well known for the production of gemstones and crystals, Cristalina is also recognised here for inhabiting 'precious' plants.

Distribution and habitat. Pombalia cristalina is known only from open savannas and campos rupestres around the municipality of Cristalina, Goiás state, central Brazil (Figure 3).

Phenology. The species has been collected with flowers and fruits in September and October, with a single flowering record for July.

Conservation status. The municipality of Cristalina is situated at the junction of Brazil's two major highways, which link the largest cities of the country to its capital city, Brasília. This has contributed to much of the growth and urbanisation of the area at the expense of its natural ecosystems. This region is one of the most important centres of production of crystals and gemstones in Brazil (hence the name), and potential environmental effects of this industry are an intense threat to its natural habitats. Personal observations have further indicated that agriculture is a relevant threat; at least two known populations have been drastically reduced and are struggling in cultivated fields of heavily mechanised crops. There is a single occurrence of this species from a small conservation unit. Therefore, according to IUCN (2012) criteria B1a,b(i,iii), Pombalia cristalina is considered Critically Endangered (CR) based on its very limited distribution (EOO, 13,413 $\mathrm{km}^{2}$ ) and the continuing decline in the quality of its habitat. 


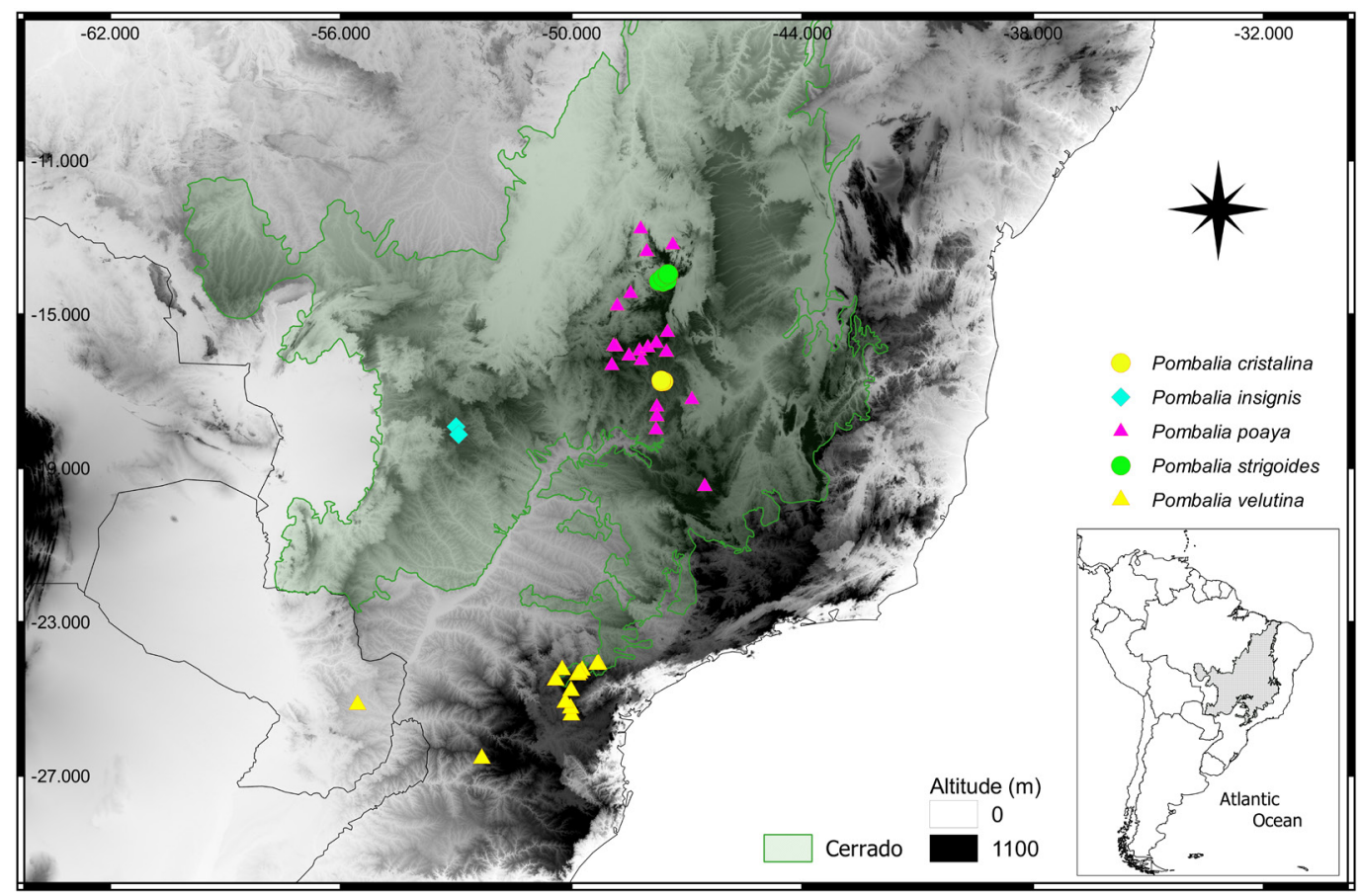

Figure 3. Distribution of Pombalia cristalina, $P$. insignis, $P$. poaya, $P$. strigoides and $P$. velutina.

Additional specimens examined. BRAZIL. Goiás: Cristalina, estrada para Unaí, c.600 m da BR 040, $16^{\circ} 44^{\prime} 43^{\prime \prime S}, 47^{\circ} 36^{\prime} 17^{\prime \prime W}, 1230$ m a.s.l., 21 i 2005, Paula-Souza et al. 4326 (ESA); c. $5 \mathrm{~km}$ da cidade em direção a Brasília, margem da BR-040, 29 vii 2007, M.A.Silva 6154 (ESA, IBGE); BR-251 c. 1 km da cidade em direção a Brasília, 8 ix 2002, M.A.Silva \& M.J.0.Souza 5363 (ESA, IBGE); 4 km de Cristalina em direção a Unaí (GO-309), Serra dos Cristais, 10 ix 1998, Paula-Souza et al. 2746 (ESA, SPF); estrada para a Pedra Chapéu do Sol, c.400 m E da BR 040, 1644'48.2"S, 47³6'26.2"W, 1235 m a.s.l., 21 x 2012, Paula-Souza et al. 11237/611 (ESA).

The habit of this new species resembles that of Pombalia strigoides, but it has slightly larger leaves. In respect to floral features, a striking difference between the two species is in the connective scales of the anthers (see Figure 10E,F), which are much larger in Pombalia strigoides. Additional differences are listed in the Table.

2. Pombalia insignis Paula-Souza, sp. nov.

Pombalia insignis is morphologically similar to Pombalia lanata (A.St.-Hil.) Paula-Souza but is distinguished by its larger flowers with anterior petal c. $27-30 \times 28-29.5 \mathrm{~mm}$ (versus 16-18.5 × 13-22 mm) and larger, c.1.5 mm long, orange-brown connective appendages (versus smaller, $0.3-0.5 \mathrm{~mm}$ long, hyaline connective appendages). Type: Brazil, Goiás, Chapadão do Céu, Parque Nacional das Emas, cerrado queimado recentemente, próximo ao portão Jacuba, Abundante ao longo da estrada beirando a 
Table. Diagnostic features of species of the Pombalia lanata complex

\begin{tabular}{|c|c|c|c|c|c|c|}
\hline Character & P. cristalina & $P$. insignis & P. lanata & P. poaya & P. strigoides & $P$. velutina \\
\hline Indument & $\begin{array}{l}\text { Strigose } \\
\text { (Figure } \\
2 A, B)\end{array}$ & $\begin{array}{l}\text { Velutinous } \\
\text { to villous, } \\
\text { the hairs } \\
\text { grouped } \\
\text { in tufts } \\
\text { ('stellate') }\end{array}$ & $\begin{array}{l}\text { Tomentose to } \\
\text { densely villous, } \\
\text { less frequently } \\
\text { pubescent, the } \\
\text { hairs usually } \\
\text { grouped in tufts } \\
\text { ('stellate') (Figures } \\
1 \mathrm{~A}, \mathrm{~B}, 5 \mathrm{C} \text { ) }\end{array}$ & $\begin{array}{l}\text { Spreading } \\
\text { villous } \\
\text { (Figure 5E) }\end{array}$ & $\begin{array}{l}\text { Strigose } \\
\text { (Figures 1C, } \\
\text { 9D) }\end{array}$ & $\begin{array}{l}\text { Tomentose } \\
\text { to villous or } \\
\text { woolly, the } \\
\text { hairs grouped } \\
\text { in tufts } \\
\text { ('stellate') } \\
\text { (Figures 1D,E, } \\
\text { 9G) }\end{array}$ \\
\hline $\begin{array}{l}\text { Leaf size } \\
(\mathrm{mm})\end{array}$ & $\begin{array}{l}10-14 \times \\
3-4.4\end{array}$ & $\begin{array}{l}20-39 \times \\
9-14\end{array}$ & $15-36 \times(5.5) 7-15$ & $\begin{array}{l}\text { (9) } 10-21.6 \times \\
6-11.5\end{array}$ & $\begin{array}{l}4-7.9 \times \\
1.5-3\end{array}$ & $\begin{array}{l}17-33 \times \\
6-12.5\end{array}$ \\
\hline $\begin{array}{l}\text { Corolla } \\
\text { colour }\end{array}$ & $\begin{array}{l}\text { White or } \\
\text { creamy }\end{array}$ & Bright blue & $\begin{array}{l}\text { Deep violet, blue, } \\
\text { light blue, lilac, } \\
\text { white, greenish or } \\
\text { yellowish }\end{array}$ & $\begin{array}{l}\text { White, } \\
\text { purplish or } \\
\text { lilac }\end{array}$ & $\begin{array}{l}\text { Purple, blue } \\
\text { or lilac, rarely } \\
\text { white }\end{array}$ & White \\
\hline $\begin{array}{l}\text { Margin of } \\
\text { sepals }\end{array}$ & Entire & Entire & Entire & Entire & Entire & Fimbriate \\
\hline $\begin{array}{l}\text { Size of } \\
\text { anterior petal } \\
(\mathrm{mm})\end{array}$ & $\begin{array}{l}13-15 \times \\
6.7-18\end{array}$ & $\begin{array}{l}27-30 \times \\
28-29.5\end{array}$ & $16-18.5 \times 13-22$ & $\begin{array}{l}15-17.5 \times \\
14-19.5\end{array}$ & $\begin{array}{l}14.5-17.5 \times \\
16-22\end{array}$ & $\begin{array}{l}13-17 \times \\
11-25\end{array}$ \\
\hline $\begin{array}{l}\text { Connective } \\
\text { appendages } \\
\text { colour }\end{array}$ & Hyaline & $\begin{array}{l}\text { Orange- } \\
\text { brown }\end{array}$ & Hyaline & Hyaline & $\begin{array}{l}\text { Hyaline } \\
\text { (Figure 9C) }\end{array}$ & Hyaline \\
\hline $\begin{array}{l}\text { Length of } \\
\text { connective } \\
\text { appendages } \\
(\mathrm{mm})\end{array}$ & c. 0.3 & c. 1.5 & $0.3-0.5$ & $0.3-0.5$ & $1-1.2$ & $0.3-0.5$ \\
\hline $\begin{array}{l}\text { Geographical } \\
\text { distribution }\end{array}$ & $\begin{array}{l}\text { Known only } \\
\text { from the } \\
\text { municipality } \\
\text { of Cristalina } \\
\text { (Goiás } \\
\text { state, Brazil) } \\
\text { (Figure 3) }\end{array}$ & $\begin{array}{l}\text { Known only } \\
\text { from Emas } \\
\text { National } \\
\text { Park (Goiás } \\
\text { state, Brazil) } \\
\text { (Figure 3) }\end{array}$ & $\begin{array}{l}\text { Widely distributed } \\
\text { throughout the } \\
\text { Brazilian Plateau } \\
\text { and Espinhaço } \\
\text { Range in Minas } \\
\text { Gerais state, Brazil, } \\
\text { with a disjunction in } \\
\text { Misiones province, } \\
\text { Argentina (Figure 7) }\end{array}$ & $\begin{array}{l}\text { Brazilian } \\
\text { Plateau, less } \\
\text { frequent } \\
\text { at the } \\
\text { Espinhaço } \\
\text { Range in } \\
\text { Minas Gerais } \\
\text { state, Brazil } \\
\text { (Figure 3) }\end{array}$ & $\begin{array}{l}\text { Endemic to } \\
\text { Chapada dos } \\
\text { Veadeiros } \\
\text { (Goiás } \\
\text { state, Brazil) } \\
\text { (Figure 3) }\end{array}$ & $\begin{array}{l}\text { Southern São } \\
\text { Paulo through } \\
\text { Rio Grande } \\
\text { do Sul states } \\
\text { in Brazil and } \\
\text { adjacent } \\
\text { areas of } \\
\text { Paraguay } \\
\text { (Figure 3) }\end{array}$ \\
\hline
\end{tabular}

rodovia, 8 km da sede em Chapadão do Céu, 11 x 2006, J. Paula-Souza, G.O. Romão \& G.S. Leite 8215 (holotype SPF [SPF188140], isotype BHO). Figures 2E,F, 4.

Suffrutescent herb, 30-50 cm high, branched from a well-developed, bud-bearing underground root-like system, erect; stems velutinous to villous, internodes $9-24 \mathrm{~mm}$. Stipule c. $1.5 \times 0.5 \mathrm{~mm}$, triangular to linear, margin entire, hyaline and inconspicuous among the dense indument; leaves alternate, sessile; blade 20-39 ×9-14 mm, lanceolate to oval, oblong, less frequently oblanceolate, apex acute to obtuse, margin entire to subentire, base round, velutinous to villous, the hairs grouped in tufts. Flowers bright blue with a yellow spot at the base of the anterior petal, solitary, axillary; pedicel 8-10 mm long, velutinous 


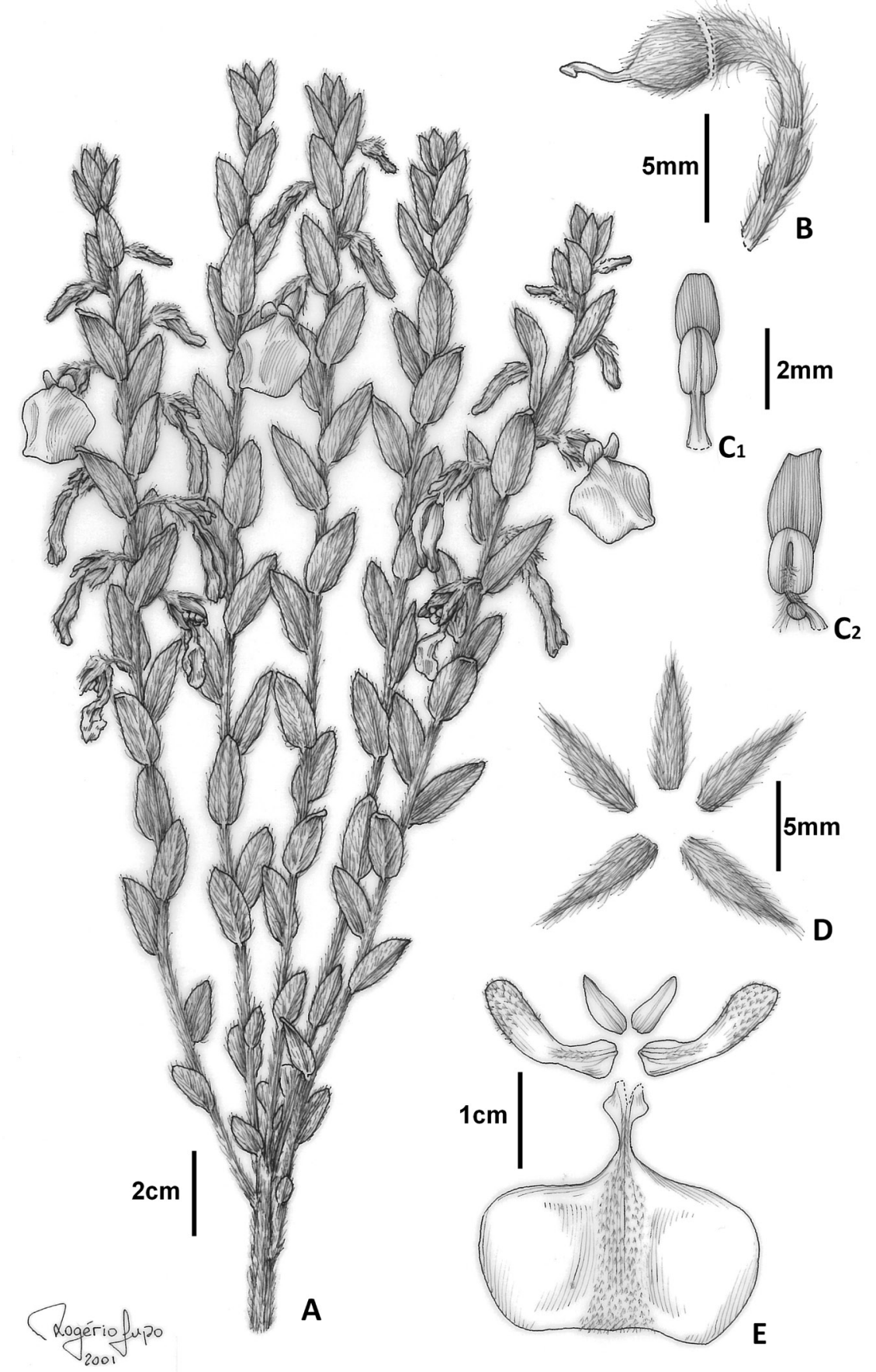

Figure 4. Pombalia insignis Paula-Souza, sp. nov.: A, habit; $B$, gynoecium; $C_{1}$, posterior stamen; $C_{2}$, anterior stamen; $D$, calyx; $E$, corolla. Drawn from Batalha 3937 by Rogério Lupo. 
to villous; bracteoles c. $1.5 \times 0.5 \mathrm{~mm}$, linear, hyaline and inconspicuous among the dense indument; sepals slightly unequal, 7-8.5 $\times$ c. $2 \mathrm{~mm}$, lanceolate, apex acute to subacuminate, margin entire, base truncate, villous; posterior petals c.7.5 $\times$ c. $3 \mathrm{~mm}$, lanceolate to slightly oval, subfalcate, apex acute; lateral petals c. $16 \times 4 \mathrm{~mm}$, oblong, slightly constricted in the middle, falcate, apex round to truncate, sparsely villous beneath; anterior petal 27-30 x 28-29.5 mm, including a claw c. $10 \mathrm{~mm}$ long, transversely oblong, apex truncate, base obtuse to truncate, smooth, villous beneath; filaments c. $1.5 \mathrm{~mm}$ long, anthers c. $1.5 \mathrm{~mm}$ long, connective appendages orange-brown, c. $1.5 \mathrm{~mm}$ long, apex truncate to emarginate, asymmetrical, the 2 anterior stamens each bearing a noduliform gland at the base of the anthers, villous; style $3.5 \mathrm{~mm}$ long, glabrous, ovary $4 \mathrm{~mm}$ long, villous, ovules unknown. Capsule 8-10 × 7-8 mm, ovoid or ellipsoid; seeds $2.8-3 \times$ c.1.8 mm.

Etymology. The epithet is the Latin word for 'remarkable, outstanding', in reference to the new species' large and showy flowers compared with the other species of this group.

Distribution and habitat. Pombalia insignis has a restricted distribution, known only from a few populations in savannas of Emas National Park, Goiás state, Brazil (see Figure 3).

Phenology. Flowering and fruiting specimens were recorded in October.

Conservation status. This new species is considered endemic to Emas National Park, whose surroundings are mostly occupied by agricultural land and livestock. The limited geographical distribution $\left(\mathrm{AOO}, 8 \mathrm{~km}^{2}\right)$ and the intense anthropogenic pressures that may eventually cause decline in the quality of the species' habitats indicate a status of Critically Endangered (CR) for Pombalia insignis, according to IUCN (2012) criteria B2b(ii,iii,iv).

Additional specimens examined. BRAZIL. Goiás: Chapadão do Céu/Mineiros, Parque Nacional das Emas, $17^{\circ} 49^{\prime}-18^{\circ} 28^{\prime} \mathrm{S}, 52^{\circ} 39^{\prime}-53^{\circ} 10^{\prime} \mathrm{W}$, Batalha 3937, 5 x 1999 (ESA); Heleno 2765, s.d. (UFG).

Pombalia insignis is morphologically similar to $P$. lanata in respect to its habit. However, the new species usually grows as larger plants, reaching up to $50 \mathrm{~cm}$, and is unique for having orange-brown, large connective scales (see Figure 4B), in contrast with the reduced (except for Pombalia strigoides) and hyaline connective scales observed in the remaining species of the Pombalia lanata complex (e.g. Figures 6E, 8D). Additional diagnostic features are listed in the Table.

3. Pombalia lanata (A.St.-Hil.) Paula-Souza, Phytotaxa 183(1): 9 (2014). - Ionidium lanatum A.St.-Hil., Ann. Sci. Nat., Ser. 1, 2: 254 (1824). Type: Brazil, Minas Gerais, "Paturages herbeus pr. Tejuco dans le District des diamans, campis", 1817, St. Hilaire Catal. B1 no. 2080 (lectotype P! [P02141267], designated by Paula-Souza in Paula-Souza \& Ballard, 2014) - Solea lanata (A.St.-Hil.) Spreng., Syst. Veg. 4(2): 97 (1827). - Hybanthus lanatus (A.St.-Hil.) Baill., Traité Bot. Méd. Phan. 2: 841 (1884). - Calceolaria lanata (A.St.-Hil.) Kuntze, Revis. Gen. PI. 1: 41 (1891). - Hybanthus lanatus (A.St.-Hil.) Taub., Nat. Pflanzenfam. 3(6): 333 (1895). Figures 1A,B, 5A-D, 6A-F. 


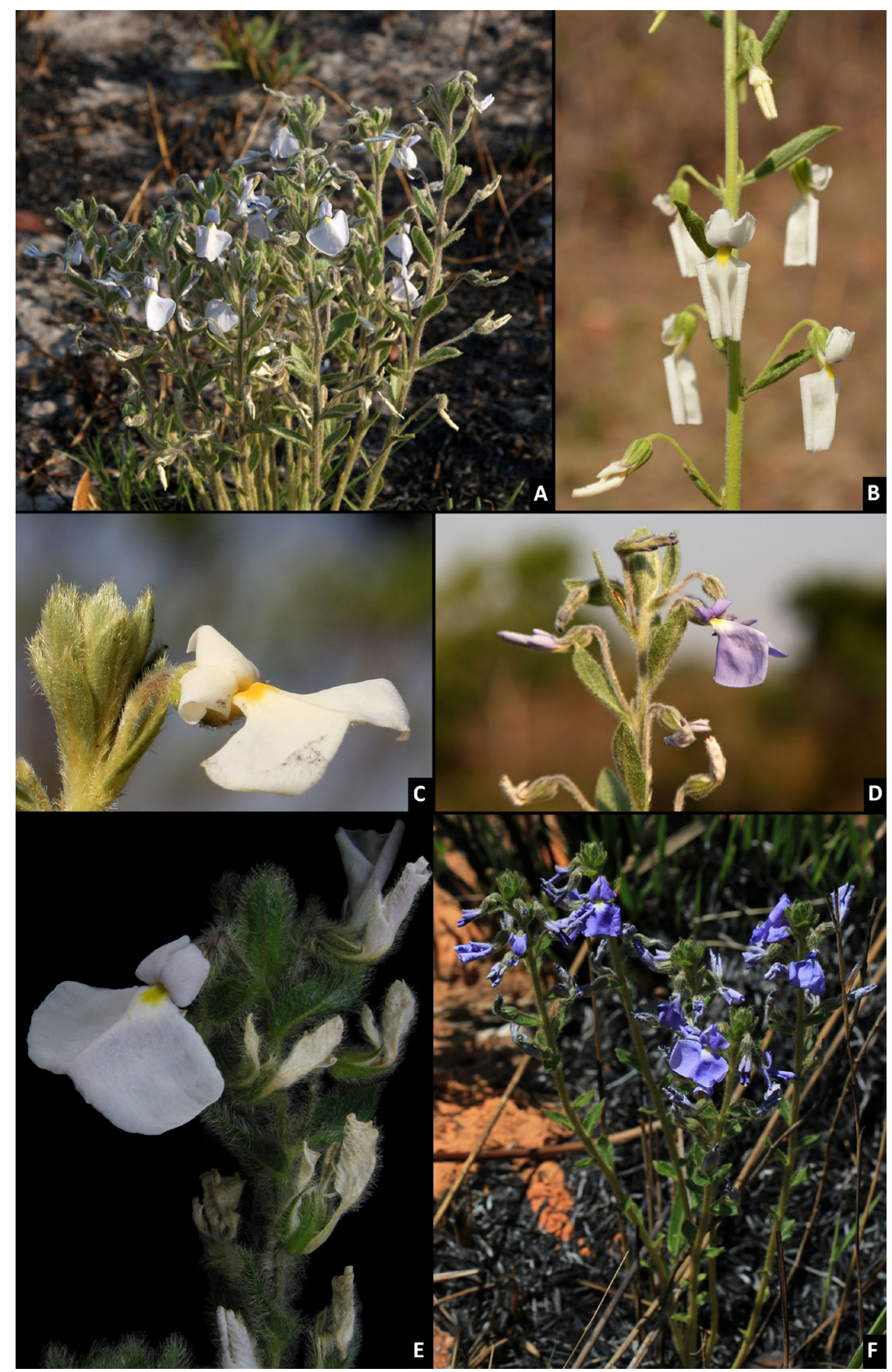

Figure 5. A-D, Pombalia lanata: A, habit; B-D, details of flowering branches, showing colour variation; $E$ and F, Pombalia poaya: E, detail of flowering branch; F, habit. Photographs: $A, C, D$ and F, Henrique Moreira; B, Jair E. Q. Faria. 


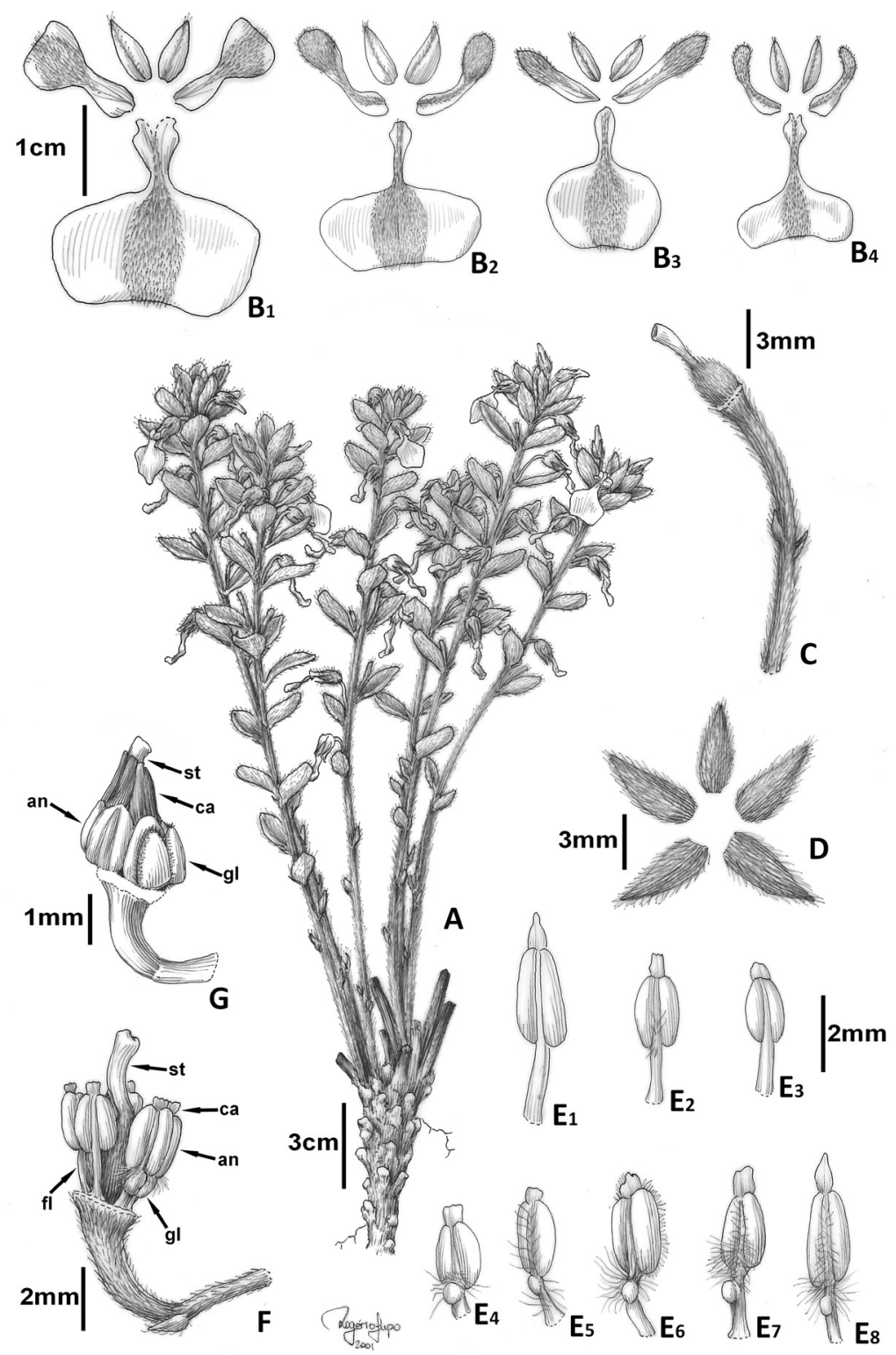

Figure 6. A-F, Pombalia lanata: A, habit; B, variation of size and shape of the corolla; C, gynoecium on the pedicel; $D$, calyx; $E_{1}-E_{3}$, variation of size, indument and shape of connective appendage of posterior stamens; $E_{4}-E_{8}$, variation of size, indument and shape of connective appendage of anterior stamens; F, typical configuration of the androecium in the Pombalia lanata complex. G, Pombalia atropurpurea: typical configuration of the androecium in the remaining hybanthoid lineages (an, anther; ca, connective appendage; $f l$, filament; $g l$, nectary gland; st, style). A-F, modified from Paula-Souza et al., 2011, and reproduced with the permission of the Conservatoire et Jardin botaniques de Genève; G, drawn from Souza 3545. Illustration by by Rogério Lupo. 
Ionidium lanatum A.St.-Hil. var. dentatum A.St.-Hil. ("dentata”), Mém. Mus. Hist. Nat. 11: 484 (1824). - Type: Brazil, "Retiro pr. pago Contendas in deserto flum, S. Francisco", Saint Hilaire s.n. (lectotype P! [P2141270], designated here; isolectotype P! [P21412701]), syn. nov. Ionidium lacteum S.Moore, Trans. Linn. Soc. London, Bot., Ser. 2, 4: 307 (1895). - Type:

Brazil, Mato Grosso: “In campis ad Serra da Chapada alt. circa 1800 ped.", 1901-1902, Moore 187 (holotype BM! [BM000626822]), syn. nov.

Hybanthus subpoaya Schulze-Menz, Notizbl. Bot. Gart. Berlin-Dahlem 12(111): 112 (1934).

- Type: Brazil, "Goyaz [currently Tocantins]. Sandy campos banks of the Rio Manoel Alvez, near the Miguari do Ouro, 1842", Gardner 3006 (holotype Bt; lectotype BM! [BM000617712], designated here; isolectotype E!, F!, G!, K!, P!), syn. nov.

Suffrutescent herb, 15-20 cm high, branched from a well-developed, bud-bearing underground root-like system, erect; internodes $5-18 \mathrm{~mm}$. Stipule $3.5-6 \times 0.5-1 \mathrm{~mm}$, margin entire; leaves alternate, subsessile; blade 15-36 × (5.5)7-15 mm, oblong, ovate, elliptic, obovate to oblanceolate, less frequently lanceolate or suborbicular, apex acute to obtuse or less frequently rounded, apiculate, margin entire or irregularly serrate at the apex, base acute to attenuate, tomentose to densely villous, less frequently pubescent, hairs all stellate or frequently simple with sparse or rare stellate hairs. Flowers deep violet, blue, light blue, lilac, white, greenish or yellowish, with a yellow spot at the base of the anterior petal, solitary, axillary; pedicel 11-21 mm, tomentose to villous; bracteoles 1-1.5 × c.0.5 mm; sepals equal, 5-8(10) $\times 1.5-3 \mathrm{~mm}$, lanceolate to ovate, frequently subfalcate, margin entire, base truncate, tomentose to villous; posterior petals 5.5-8 $\times 1-3 \mathrm{~mm}$, ovate or oblong, subfalcate; lateral petals $10.5-16.3 \times 2-5(12) \mathrm{mm}$, spatulate to oblong, frequently constricted at the central portion, falcate, rarely clawed, tomentose to villous at apex; anterior petal 16-18.5 $\times$ 13-22 mm including a claw 7-9 mm long, oblate, deltoid, transversely oblong or elliptic, or widely transversely rhombic, apex truncate, emarginate or obtuse, smooth, tomentose to villous; filaments $1-2 \mathrm{~mm}$, connective appendages hyaline, $0.3-0.5 \mathrm{~mm}$ long, nectar glands noduliform, frequently much reduced, inserted on the filaments usually near the base of the anthers, subglabrous to villous; style $3-4 \mathrm{~mm}$, glabrous or rarely tomentose at the base, straight or less frequently subsigmoid, ovary $2-2.5 \mathrm{~mm}$, villous. Capsule $8.5-10 \times$ 6-7.5 mm, ellipsoid to ovoid; seeds c. $3 \times 2-2.5 \mathrm{~mm}$.

Vernacular name. Poaia (Brazil).

Etymology. The epithet lanata ('woolly') refers to the dense indument typical of this species.

Distribution and habitat. Pombalia lanata occurs in savannas, grasslands and campos rupestres of the Brazilian Plateau from Tocantins to Mato Grosso do Sul, also reaching Espinhaço Range in Minas Gerais, with a disjunction in Misiones province, Argentina (Figure 7; see also Paula-Souza et al., 2011). The collection Gardner 2397 at K registered for Ceará state is probably a case of mixed labels, because there is a gathering of Pombalia 


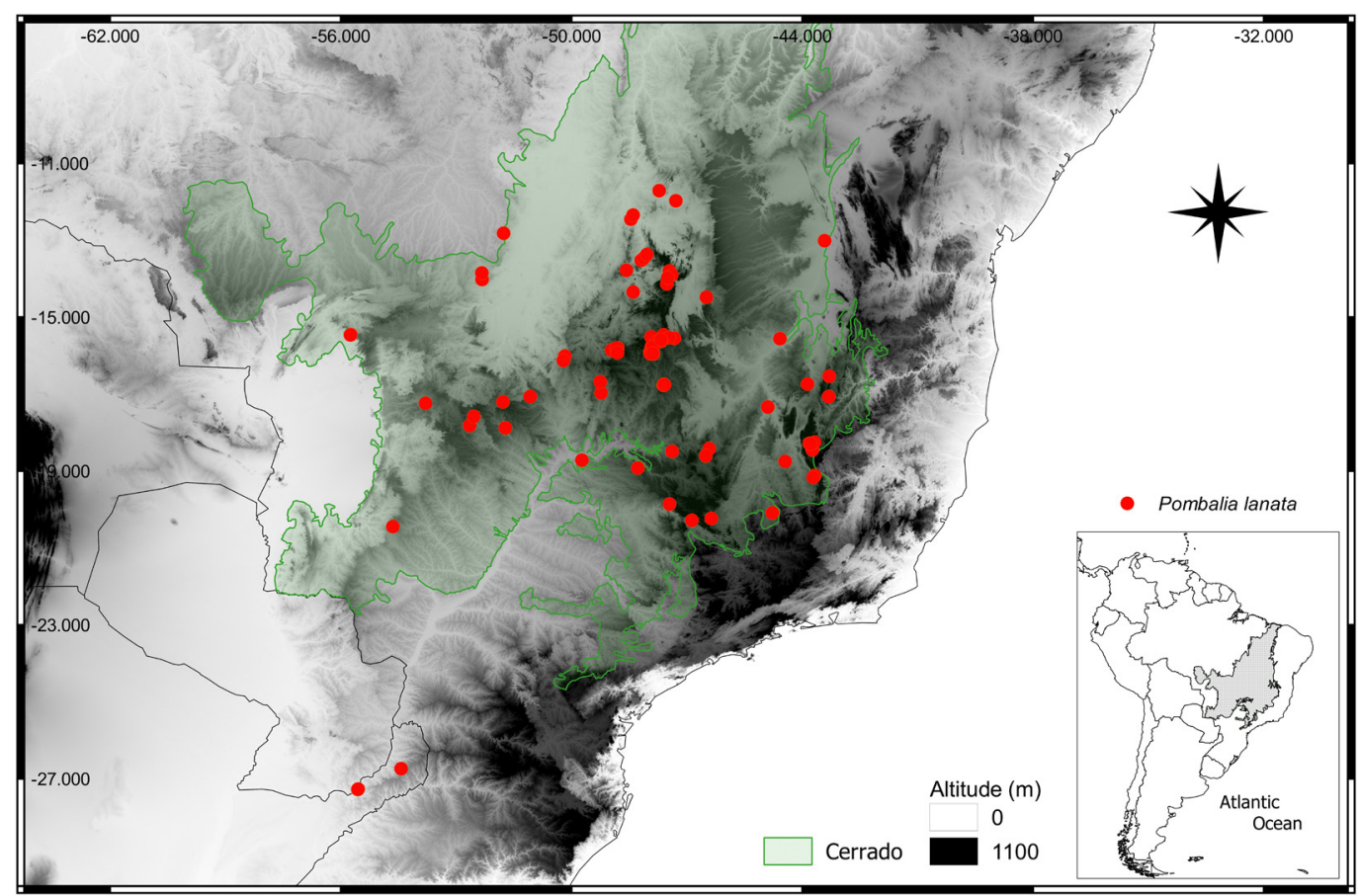

Figure 7. Distribution of Pombalia lanata.

arenaria by Gardner with the same number from the same location ("Cachoeira"), which is situated in a typical xerophytic, deciduous Caatinga vegetation quite distant from the known geographical limits of $P$. lanata.

Phenology. The species has been collected with flowers and fruits throughout the year, but most specimens were collected from July to November, peaking in September and October.

Conservation status. This is the most widely distributed species of the Pombalia lanata complex (EOO, 1,554,464 km²; AOO, $152 \mathrm{~km}^{2}$ ), with abundant records in conservation units. Pombalia lanata is thus assigned a conservation status of Least Concern (LC).

Selected specimens examined. ARGENTINA. Misiones: San Ignácio, Teyucuaré, $27^{\circ} 16^{\prime} \mathrm{S}, 55^{\circ} 33^{\prime} \mathrm{W}, 150 \mathrm{~m}$ a.s.I., 19 ix 2000, Múlgura de Romero et al. 2065 (MO, NY, SI).

BRAZIL. Distrito Federal: Brasília, APA Gama-Cabeça de Veado, região administrativa do Núcleo Bandeirante, ARIE do Córrego do Cedro, SMPW-Q.26 Conj. 3, 1554'49"S, 4757'50"W, 1050 m a.s.I., 14 x 2002, Fonseca et al. 3671 (IBGE, RB); Planaltina, Área de Chapadão BR-020, Sobradinho-Planaltina, km 15, à direita da rodovia, $15^{\circ} 37^{\prime} 00^{\prime \prime S}, 47^{\circ} 42^{\prime} 30 " W, 900 \mathrm{~m}$ a.s.I., 1 ix 1994, J.C. Silva 739 (CEN); Vargem Bonita, APA do Gama - Cabeça de Veado (RA) Núcleo Bandeirante, Park Way, Lagoa do Córrego do Cedro na entrada para a Vargem Bonita, 1553'51.8"S, 4756'39.8"W, 990 m a.s.l., 11 ix 2002, Mendonça et al. 5018 (IBGE, RB). Goiás: Alto Paraíso de Goiás, Parque Nacional da Chapada dos Veadeiros, Pouso Alto, $13^{\circ} 58^{\prime} 26 " S, 47^{\circ} 29^{\prime} 59^{\prime \prime}$ W, 1546 m a.s.l., 26 xi 2014, Verdi et al. 7311 (CEN, RB); Alvorada do Norte, Rod. BR 020, 25 km S de Alvorada do Norte, 11 x 1976, Hatschbach 39133 (MBM); Barro Alto, área 
da mineradora Anglo American Brasil, 1506'06.2"S, 4900'43"W, 7 vii 2017, Pachêco et al. 68 (CEN); Caiapônia, Serra do Caiapó, c. $33 \mathrm{~km} \mathrm{~S}$ of Caiapônia on road to Jataí, $17^{\circ} 12^{\prime} \mathrm{S}, 51^{\circ} 47^{\prime} \mathrm{W}, 800-1000 \mathrm{~m}$ a.s.I., 18 x 1964, Irwin \& Soderstrom 6995 (COL, MO, NY); Campinaçu, depois de Buriti, km 18, estrada vicinal, $13^{\circ} 31^{\prime} 08^{\prime \prime S}, 48^{\circ} 11^{\prime} 14^{\prime \prime W}, 330$ m a.s.I., 5 x 2000, Cavalcanti et al. 2669 (CEN); Cavalcante, estrada Balsa Porto dos Paulistas (rio Tocantins) para HU, c.32 km da balsa, $13^{\circ} 22^{\prime} 52^{\prime \prime} \mathrm{S}, 48^{\circ} 00^{\prime} 00^{\prime \prime} \mathrm{W}, 760 \mathrm{~m}$ a.s.I., 9 xi 2000, G.P. Silva et al. 4408 (CEN); Chapadão do Céu/Mineiros, Parque Nacional das Emas, próxima ao ponto $\mathrm{J}, 17^{\circ} 49^{\prime}-18^{\circ} 28^{\prime} \mathrm{S}, 52^{\circ} 39^{\prime}-53^{\circ} 10^{\prime} \mathrm{W}, 10$ ix 1999 , Batalha 3885 (ESA); Cocalzinho, Serra dos Pireneus, Parque Estadual da Serra dos Pireneus, após a 2a. porteira, saindo da Faz. Capitão do Mato, sentido para o Morro do Cabeludo, 154' S, 4848'W, 24 x 2004, Delprete et al. 8981 (NY, SPF); Corumbá de Goiás, Serra do Bicame, estrada para Pirenópolis, 1 viii 1984, Pereira et al. 1093 (IBGE,

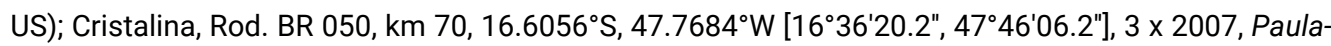
Souza et al. 8753 (SPF); Formosa, 19 x 1965, A.P. Duarte 9379 (RB); Goiânia, na GOM-9, p/ Nerópolis, 2 km da Esc. Agron. e Veterinária, 1 xii 1968, Rizzo \& Barbosa 2841 (UFG); Hidrolândia, Morro Feio, 8 xi 2007, Pastore 2257 (HUEFS); Jataí, estrada de Jataí para Serranópolis, a 20 km do Ribeirão Ariranha, 18 x 1972, Rizzo 8474 (ESA, UFG); Mineiros, Rod. BR 364, prox. Córrego Alegre, 20 ix 1974, Hatschbach et al. 35015 (MBM); Mossâmedes/Goiás, Serra Dourada, área da UFG, s.d., Rizzo 4484 (RB, UFG); Niquelândia, Companhia de Níquel de Tocantins - CNT; estrada à esquerda da mina de níquel, c. $2 \mathrm{~km}$ da entrada, 1040 m a.s.l., 14²0'37"S, 48²3'57"SW, s.d., Mendonça et al. 3097 (IBGE, RB); Pirenópolis, Parque Estadual da Serra dos Pireneus, estrada para o Morro do Cabeludo, c.500 $\mathrm{m}$ da estrada principal, $15^{\circ} 48^{\prime} 00.4^{\prime \prime}, 48^{\circ} 49^{\prime} 41.6^{\prime \prime}, 1324$ m a.s.l., 25 x 2012, Paula-Souza et al. 11354/728 (ESA); Planaltina, GO-118, próximo ao km 0 (divisa GO-DF), $33 \mathrm{~km}$ S de São Gabriel, $15.5116^{\circ} \mathrm{S}, 47.5283^{\circ} \mathrm{W}$ [1530'41.8"S, 47³1'41.9"W], 3 x 2007, Paula-Souza et al. 8792 (SPF); Teresina de Goiás, Faz. Hotel Ecológico Alpes Goianos, Rod. GO-118, km 202, 1353'59.1"S, 47²3'48.9"W, 31 vii 2000, J.P. Souza et al. 3543 (ESA). Mato Grosso: Chapada dos Guimarães, Sta. Anna da Chapada, 20 ix 1902, Robert 547 (BM, K); Itiquira, c.23 km leste de Itiquira na estrada MT-299 a Alto Araguaia, $17^{\circ} 14^{\prime} 12^{\prime \prime} \mathrm{S}, 53^{\circ} 47^{\prime} 50^{\prime \prime} \mathrm{W}$, $550 \mathrm{~m}$ a.s.l., 17 ix 1995, Pott et al. 7376 (CPAP); Xavantina, c. $70 \mathrm{~km} \mathrm{~N}$ of Xavantina, $14^{\circ} 40^{\prime} \mathrm{S}, 52^{\circ} 20^{\prime} \mathrm{W}$, 300-400 m a.s.l., 10 x 1964, Irwin \& Soderstrom 6727 (UB). Mato Grosso do Sul: Campo Grande, Estaca, 10 ix 1936, Archer \& Gehrt 164 (SP, US). Minas Gerais: Abadia dos Dourados, arid upland campo N. d'Abadia, v 1840, s.col. 4091 (K); Curvelo, início da Serra do Espinhaço, 50 km de Diamantina, 3 x 1980, Ferreira et al. 1477 (RB); Delfinópolis, estrada para Gurita, 20¹6'52"S, 4652'16"W, 816 m a.s.l., 21 x 2003, Volpi et al. 730 (HUFU, RB); Diamantina, Rapadura, 1280 m a.s.l., 29 iv 1931, Mexia 5710a (BM, F, G, GH, K, MO, NY, US); Gouveia, Serra do Espinhaço, rodovia para Barão do Guaçuí, $1300 \mathrm{~m}$ a.s.l., $24 \mathrm{x}$ 1999, Hatschbach et al. 69629 (CTES, MBM, NY); Itacambira, 1700.57,2"S, 43²0.26,6"W [1700'57.2", 4320'26.6"], 1300 m a.s.l., 13 xi 2001, Tozzi \& Alencar 2001-478 (UEC); Monte Azul, c.23 km SE de Monte Azul, 1331 m a.s.I., 27 x 2010, Queiroz et al. 14974 (HUEFS); Montes Claros, Serra do Catuny, Brejo das Almas, 1000 m a.s.l., 10 xi 1938, Markgraf et al. 3230 (F, R, RB); Patos de Minas, entre Patos de Minas e Pirapora, 16 ix 1963, R.S. Silva s.n. (HB [HB28626]); Pirapora, 17 km de Pirapora, rumo BR-7, 13 x 1962, Pabst 7112 (COL, HB, NY); Presidente Olegário, em direção a Coromandeo, $26 \times 1966, L$. Duarte 876 (HB); Rio Pardo de Minas, Sítio do Sr. José, 15³1'57"S, 47²7'32"W, 900 m a.s.l., 6 xi 2006, Sevilha et al. 4713 (CEN); Sacramento, PARNA Serra da Canastra, próximo à guarita de Sacramento, 19 viii 1994, Nakajima et al. 413 (ESA, HUFU); Salgado, Brasilia in herbidis umbrosis, s.d., Martius s.n. (M); Santana do Riacho, Serra do Cipó, ao lado da Pensão Chapéu de Sol, 6 vii 2001, J.P. Souza et al. 3583 (ESA); São Roque de Minas, Parque Nacional da Serra da Canastra, $53.8 \mathrm{~km}$ W do centro de visitantes e $15 \mathrm{~km}$ E da portaria de Sacramento, $20^{\circ} 08^{\prime} 17^{\prime \prime S}, 46^{\circ} 47^{\prime} 07.7^{\prime \prime W}, 1367$ m a.s.l., 3 ix 2015, Pirani et al. 
6612 (SPF); Sopa, près de Biribiry, 1892, Glaziou 18871 (K, P); Uberlândia, Estação Ecológica do Panga, 29 ix 1992, Barbosa 872 (ESA, HUFU). Tocantins: Natividade, Serra de Natividade, xii 1839, Gardner $3196(\mathrm{~K})$.

This is the most morphologically variable species within the Pombalia lanata complex, and this variation led to the description of many names that are here treated as synonyms (Ionidium lanatum A.St.-Hil. var. dentatum A.St.-Hil., I. lacteum S.Moore and Hybanthus subpoaya Schulze-Menz). Although specimens showing intermediate characteristics might impose some difficulty in identification, Pombalia lanata can be distinguished from the remaining species of the group by a set of features listed in the Table. Notes accompanying some herbarium specimens of Pombalia lanata report that the flowers are intensely fragrant.

4. Pombalia poaya (A.St.-Hil.) Paula-Souza, Phytotaxa 183(1): 10, f. 1A (2014). - Ionidium poaya A.St.-Hil., Ann. Sci. Nat., Ser. 1, 2: 254 (1824). Type: Brazil, “Près Sta. Luzia de Goyaz”, v 1817, St. Hilaire Catal. C1-653 (lectotype P! [P2141239], designated by Paula-Souza in Paula-Souza \& Ballard, 2014; isolectotype P! [P2141238]). - Solea poaya (A.St.-Hil.) Spreng., Syst. Veg. 4(2): 97 (1827). - Hybanthus poaya (A.St.-Hil.) Baill., Traité Bot. Méd. Phan. 2: 841 (1884). - Calceolaria poaya (A.St.-Hil.) Kuntze, Revis. Gen. Pl. 1: 41 (1891). Hybanthus poaya (A.St.-Hil.) Taub., Nat. Pflanzenfam. 3(6): 333 (1895). Figures 5E,F, 8.

Suffrutescent herb, 10-30 cm high, branched from a well-developed, bud-bearing underground root-like system, erect; internodes $2.5-31 \mathrm{~mm}$. Stipule c. $1.5 \times 0.5 \mathrm{~mm}$, margin entire; leaves alternate, sessile; blade (9)10-21.6 ×6-11.5 mm, lanceolate to ovate, narrowly oblong to oblong, narrowly elliptic to elliptic, oblanceolate, apex acute to obtuse, margin entire to sparsely serrate, base acute, rounded or cordate, spreading-villous to sparsely spreading-villous. Flowers white, purplish or lilac with a yellow spot at the base of the anterior petal, solitary, axillary; pedicel 7.2-12.3 mm, spreading-villous; bracteoles c. $0.7 \times 0.3 \mathrm{~mm}$; sepals subequal, 5-7.5 ×1.3-2 mm, lanceolate, sometimes subfalcate, margin entire, base truncate, villous; posterior petals $6.3-8.7 \times 2.5-3 \mathrm{~mm}$, lanceolate to ovate or oblong, villous at the apex; lateral petals $11-13 \times 3.4-5.7 \mathrm{~mm}$, spatulate, frequently falcate, sparsely villous to villous; anterior petal 15-17.5 × 14-19.5 mm including a claw 6.3-7 mm long, transversely oblong to subsquare, apex emarginate, smooth, villous; filaments $0.5-1.5 \mathrm{~mm}$, connective appendages hyaline, $0.3-0.5 \mathrm{~mm}$ long, nectar glands noduliform, sometimes much reduced, inserted at the base of the anthers, villous; style c. $4 \mathrm{~mm}$, glabrous, straight or subsigmoid, ovary $2 \mathrm{~mm}$, villous. Capsule 7-13 × c.7 mm, ovoid; seeds $3 \times 2-2.7 \mathrm{~mm}$.

Vernacular names. Poaia, poaia-do-campo.

Etymology. The epithet is the vernacular name of the species, which was widely used in traditional medicine in Saint-Hilaire's time.

Distribution and habitat. Pombalia poaya is found in grasslands and savannas of the Brazilian Plateau, from Maranhão to Minas Gerais states (see Figure 3). 


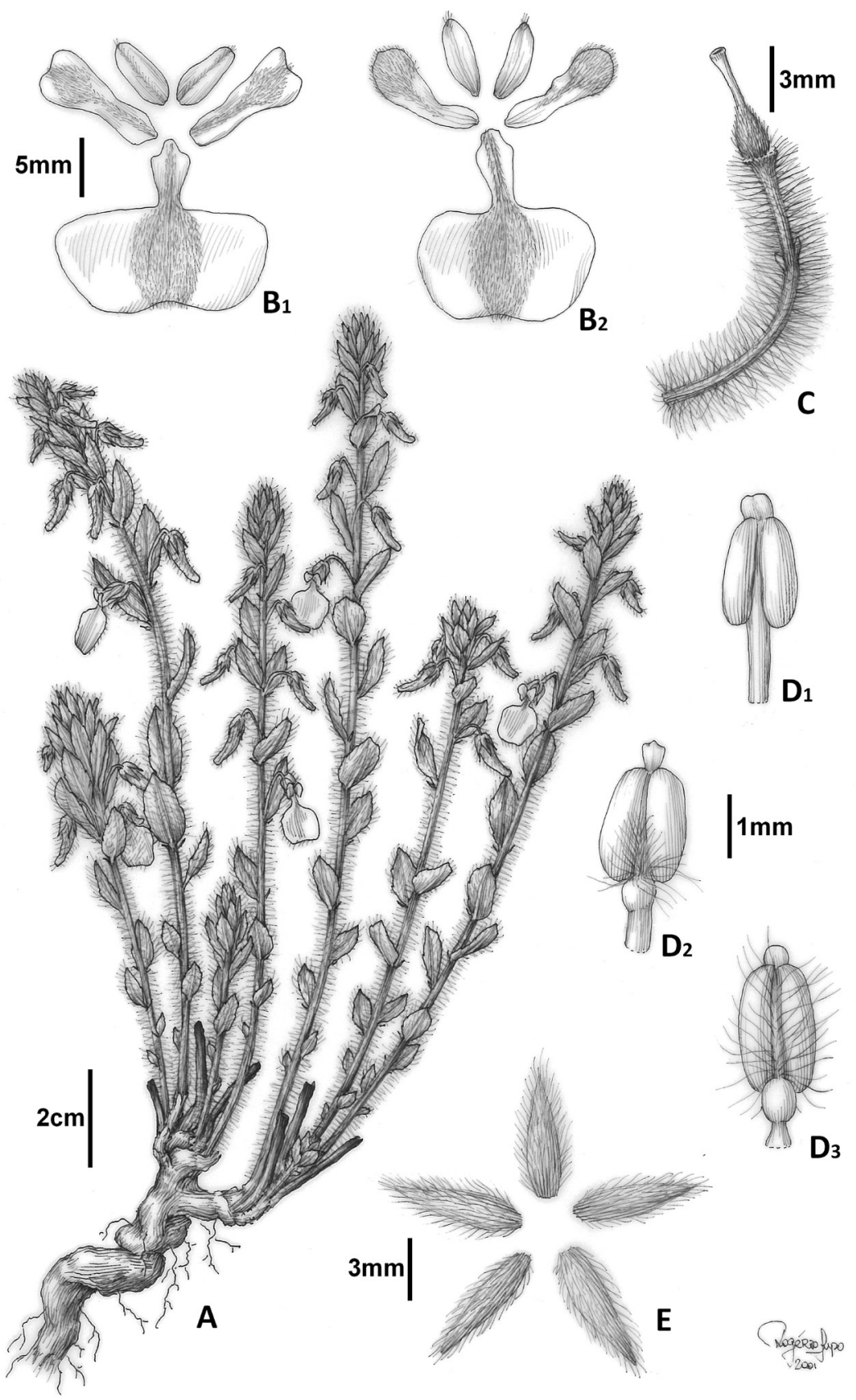

Figure 8. Pombalia poaya: A, habit; $\mathrm{B}$, variation of size and shape of the corolla; $\mathrm{C}$, gynoecium on the pedicel; $D_{1}$, posterior stamen; $D_{2}$ and $D_{3}$, variation of size, indument and shape of connective appendage of anterior stamens; E, calyx. Drawn from Brochado \& Filgueiras $06\left(A, C, D_{1}, D_{2}\right.$ and E), Souza $2744\left(B_{1}\right)$ and Salles $204\left(B_{2}\right.$ and $\left.D_{3}\right)$ by Rogério Lupo. 
Phenology. The species has been recorded in flowering and fruiting stages from July to November (rarely in May), peaking in September and October.

Conservation status. Pombalia poaya is a widespread species (EOO, 186,168 km²; AOO, $52 \mathrm{~km}^{2}$ ), with several records in conservation units, and is therefore listed as Least Concern (LC).

Selected specimens examined. BRAZIL. Distrito Federal: Brasília, Córrego Capoeira do Bálsamo, c.10 km E de Brasília, 1100 m a.s.I., 16 ix 1965, Irwin et al. 8384 (COL, UB). Goiás: Alexânia, Rod. BSB-Gyn, 7 curvas, ponte do rio Lages, 14 ix 2003, Pastore \& Bringel 698 (CEN); Alto Paraíso de Goiás, Rod. G0-118 em direção a Cavalcante, c.12 km N (em linha reta) de Alto Paraíso, 1401'37", 47³1'45.4", $1502 \mathrm{~m}$ a.s.I., 23 x 2012, Paula-Souza et al. 11311/685 (ESA); Anápolis, 18 x 1956, Smith 4821 (US); Campo Alegre de Goiás/Cristalina, c.20(?) km de Cristalina em direção a Campo Alegre de Goiás, $17^{\circ} 24^{\prime} 31^{\prime \prime S}$, 4707'01"W, 8 ix 1998, J.P. Souza et al. 2745 (ESA); Catalão, BR-050, c. 8 km S de Pires Belo, 18.0028 ${ }^{\circ}$, $47.8028^{\circ} \mathrm{W}$ [18 $\left.00^{\prime} 10.1^{\prime S}, 47^{\circ} 48^{\prime} 10.1^{\prime \prime W}\right], 2$ x 2007, Paula-Souza et al. 8774 (SPF); Cavalcante, estrada de terra saindo da balsa do Porto dos Paulistas (no rio Tocantins) para o Buracão, a c.17 km do rio, 13²2'17"S, 4802'40"W, 430 m a.s.l., 9 xi 2000, Walter et al. 4642 (CEN); Corumbá de Goiás, Pireneus, 28 vii 1952, Macedo 3714 (US); Luziânia, $1.5 \mathrm{~km}$ a oeste da ponte do rio Alagado, em direção BR-060, $16^{\circ} 12^{\prime} 01^{\prime \prime S}, 48^{\circ} 11^{\prime} 08^{\prime \prime W}, 870$ m a.s.l., 6 xi 2002, G.P. Silva et al. 6858 (CEN); Niquelândia, estrada Uruaçu-Niquelândia, c.50 km de Uruaçu, 15 vii 2000, J.P. Souza et al. 3540 (ESA, RB); Pirenópolis, Serra dos Pireneus, subida para o Parque, $15^{\circ} 49^{\prime} 29^{\prime \prime S}, 48^{\circ} 54^{\prime} 24^{\prime \prime W}, 1070 \mathrm{~m}$ a.s.I., 18 i 2005 , Paula-Souza et

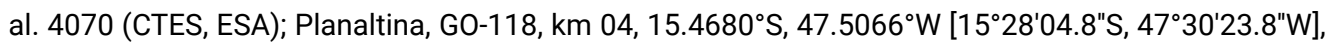
$3 \times 2007$, Paula-Souza et al. 8801 (SPF). Maranhão: Amaro Leite, Brésil central (Sertao d'Amaroleité), ix-x 1844, Weddell 2839 (P). Minas Gerais: Ibiá, Rio Santa Teresa, 12 x 1982, Hatschbach \& Kummrow 45591 (F, MBM). Tocantins: Parana, estrada de acesso à vila Rosário, fazenda Bom Retiro, 1246'49"S, 48 $12^{\prime} 10^{\prime W}, 307$ m a.s.l., 23 xi 2007, Pereira-Silva et al. 12273 (CEN).

Typical forms of Pombalia poaya are readily recognised by its spreading-villous indument. The species has been extensively used in folk medicine for the purgative, emetic and evacuant properties of the roots (Mügge et al., 2016).

5. Pombalia strigoides (Taub.) Paula-Souza, Phytotaxa 183(1): 11, f. 1F, 3G, 5B (2014). Hybanthus strigoides Taub., Bot. Jahrb. Syst. 21: 445 (1896). Type: Brazil. “Goyaz. Auf Chapadao der Morro do Salto", ix 1892, E.Ule 2752/58 (lectotype HBG! [HBG506559], designated by Paula-Souza in Paula-Souza \& Ballard, 2014; isolectotype P!, R!). Figures 1C, 9A-D, 10A-E.

Suffrutescent herb, 8-20 cm high, branched from a well-developed, bud-bearing underground root-like system, erect; internodes $2.5-16.5 \mathrm{~mm}$. Stipule c. $1 \times$ c. $0.6 \mathrm{~mm}$, margin entire; leaves alternate, sessile and usually adpressed to the stems; blade 4-7.9 $\times$ 1.5-3 mm, narrowly elliptic to elliptic, oblong, less frequently linear, apex acute, frequently obtuse or slightly acuminate, margin entire, base acute to obtuse, strigose, sometimes the hairs condensed at midrib, hairs simple, closed-pressed. Flowers purple, blue or lilac with a yellow or white spot at the base of the anterior petal, rarely white, solitary, axillary; pedicel 6.8-16.5 mm, strigose; bracteoles c. $1 \times$ c. $0.4 \mathrm{~mm}$; sepals subequal, $3.6-6.7 \times 1.1-2.4 \mathrm{~mm}$, 


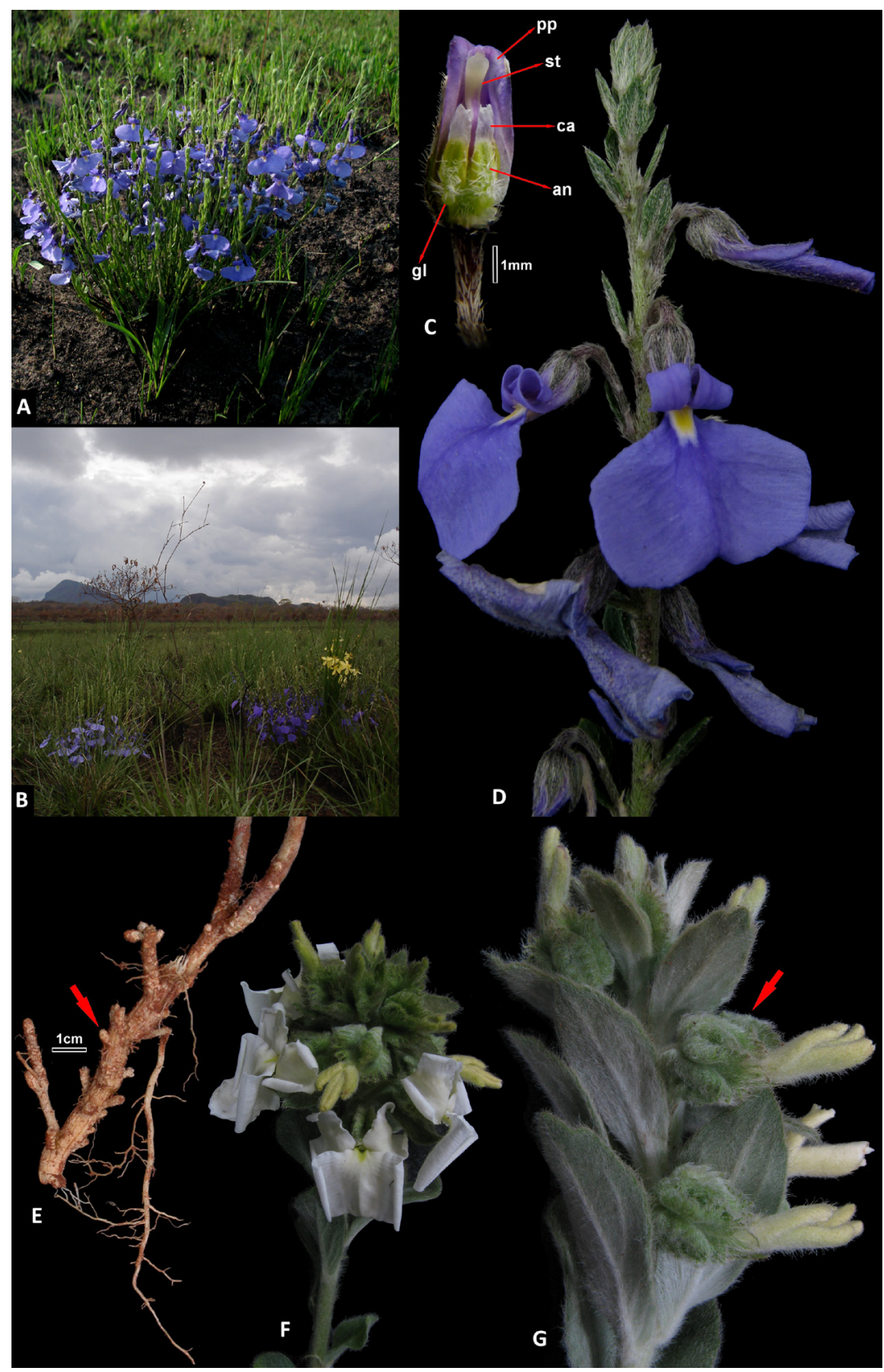

Figure 9. A-D, Pombalia strigoides: A, habit; B, habitat; $C$, configuration of the androecium around the gynoecium (an, anther; ca, connective appendage; $g l$, nectar gland; $p p$, posterior petal; st, style); D, detail of flowering branch; E-G, Pombalia velutina: E, root system (bud indicated by arrow); F, flowering branch of congested inflorescence; G, detail of broad, fimbriate sepals (arrow). Photographs by Juliana de Paula-Souza. 


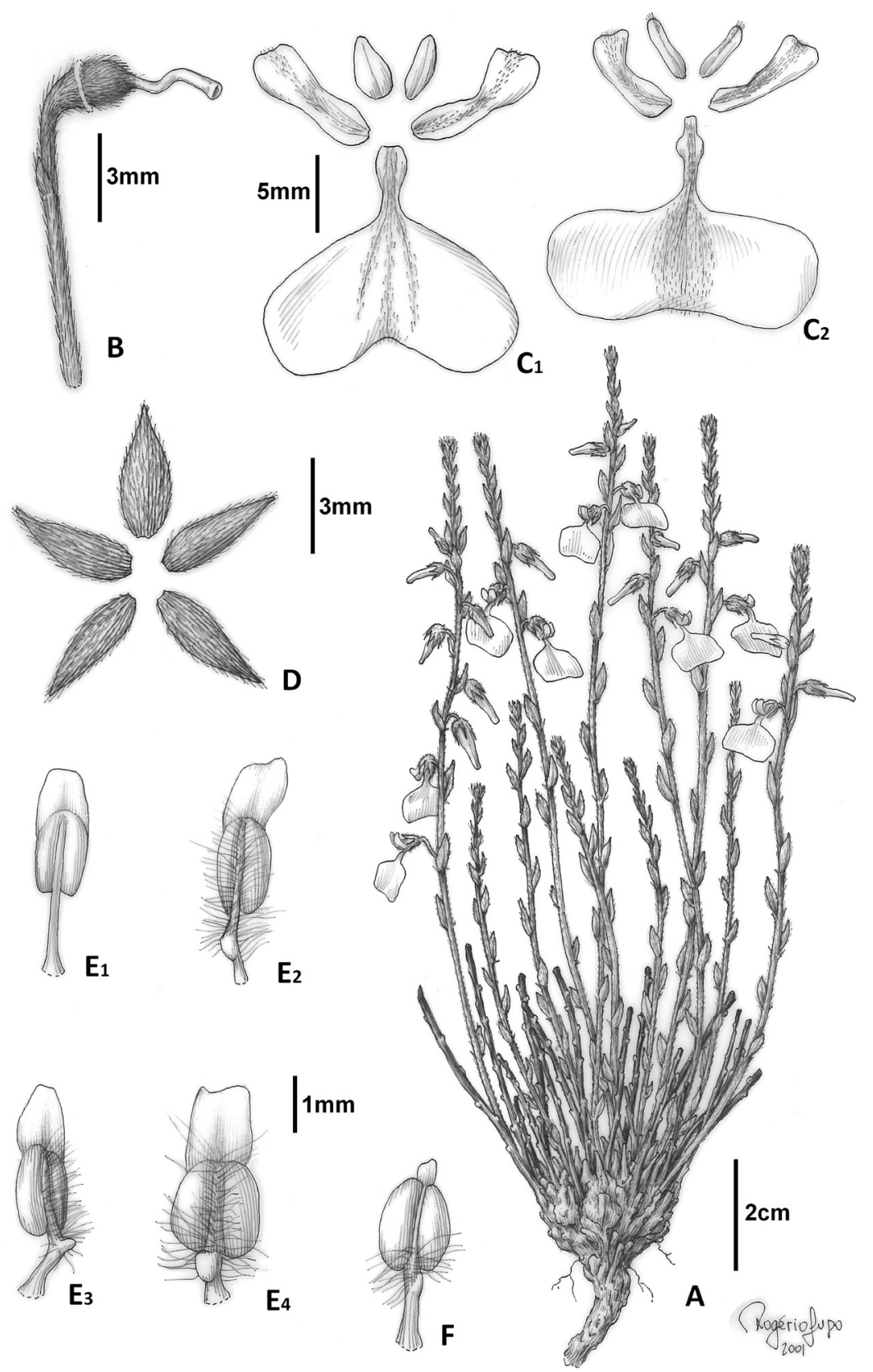

Figure 10. A-E, Pombalia strigoides: A, habit; B, gynoecium; $C$, variation of size and shape of the corolla; $D$, calyx; $E_{1}$, posterior stamen; $E_{2}-E_{4}$, variation of size, indument and shape of connective appendage of anterior stamens. F, Pombalia cristalina Paula-Souza, sp. nov.: anterior stamen. Drawn from Gifford \& Fonseca $243(\mathrm{~A})$, Irwin et al. 9355 ( $\mathrm{B}$ and $\mathrm{E}_{3}$ ), Rizzo $8407\left(\mathrm{C}_{1}, \mathrm{D}, \mathrm{E}_{1}\right.$ and $\mathrm{E}_{2}$ ), Heringer 2503 $\left(\mathrm{C}_{2}\right.$ and $\left.\mathrm{E}_{4}\right)$ and Proença \& Oliveira $1562(\mathrm{~F})$ by Rogério Lupo. 
lanceolate, frequently subfalcate, margin entire, base truncate or rounded, strigose; posterior petals 4.7-6.5 × 1.3-2.7 mm, narrowly oblong, oblong-lanceolate or less frequently ovate; lateral petals $9.5-14 \times 2.7-7 \mathrm{~mm}$, oblong, frequently constricted at the central portion, or clawed, falcate, sparsely villous; anterior petal 14.5-17.5 × 16-22 mm, including a claw 4.7-6.8 $\mathrm{mm}$ long, transversely oblong, obtriangular, apex slightly to deeply emarginate, smooth, villous; filaments 0.8-1.2 mm, connective appendages hyaline, 1-1.2 mm long, nectar glands noduliform, rarely much reduced, inserted on the filaments or near the base of the anthers, villous; style $3 \mathrm{~mm}$, glabrous, sigmoid, ovary 1.1-1.8 $\mathrm{mm}$, villous to strigose. Capsule $6 \times$ c. $6 \mathrm{~mm}$, ovoid; seeds c. $3 \times$ c. $2.5 \mathrm{~mm}$.

Etymology. The epithet refers to the plant's resemblance to species of the parasitic genus Striga Lour. (witchweed) in the Orobanchaceae.

Distribution and habitat. Pombalia strigoides is restricted to campos rupestres, grasslands and savannas of Chapada dos Veadeiros region, northeastern Goiás state, Brazil (see Figure 3).

Phenology. The species has been collected with flowers and fruits from September to November, with a single flowering record in August.

Conservation status. Although there are records of Pombalia strigoides populations within the limits of conservation units, the species has nonetheless a restricted distribution in a region marked by the conversion of natural ecosystems into agricultural areas. According to IUCN (2012) criteria B1b(i,iii) $+2 \mathrm{~b}$ (ii,iii), this species is considered Critically Endangered (CR) based on its limited distribution (AOO, $8 \mathrm{~km}^{2}$; EOO, not measurable) and the continuing decline in the quality of its habitats.

Selected specimens examined. BRAZIL. Goiás: Alto Paraíso de Goiás, Rod. G0-118 em direção a Cavalcante, c. 20 km N (em linha reta) de Alto Paraíso, 1357'40.2", 47²2'26.1", 1516 m a.s.l., 23 x 2012, Paula-Souza et al. 11341/715 (ESA, HUEFS, MBM, RB); Chapada dos Veadeiros, 27 km de Alto Paraíso/Colinas, campo limpo acima da Mata Funda, 24 xi 1994, M.A. Silva et al. 2398 (IBGE).

Typical forms of Pombalia strigoides are easily distinguished by their very reduced leaves 4-7.9 $\times 1.5-3 \mathrm{~mm}$, which are usually adpressed to the stems, and by the strigose indument of vegetative and floral parts.

6. Pombalia velutina (Schulze-Menz) Paula-Souza, Phytotaxa 183(1): 11, f. 1D, 3H (2014). Hybanthus velutinus Schulze-Menz, Notizbl. Bot. Gart. Berlin-Dahlem 12(111): 111 (1934). Type: Paraguay. "In regione fluminis Yhú", x 1905, E.Hassler 9514 (lectotype G! [G76156], designated by Seo et al., 2009; isolectotype BM!, G! [G76155, G76157, G76158]). Figures 1D,E, 9E-G, 11.

Suffrutescent herb, 15-30 cm high, branched from a well-developed, bud-bearing underground root-like system, erect; internodes 3-26 mm. Stipule 5-7 × c.0.5 mm, margin 


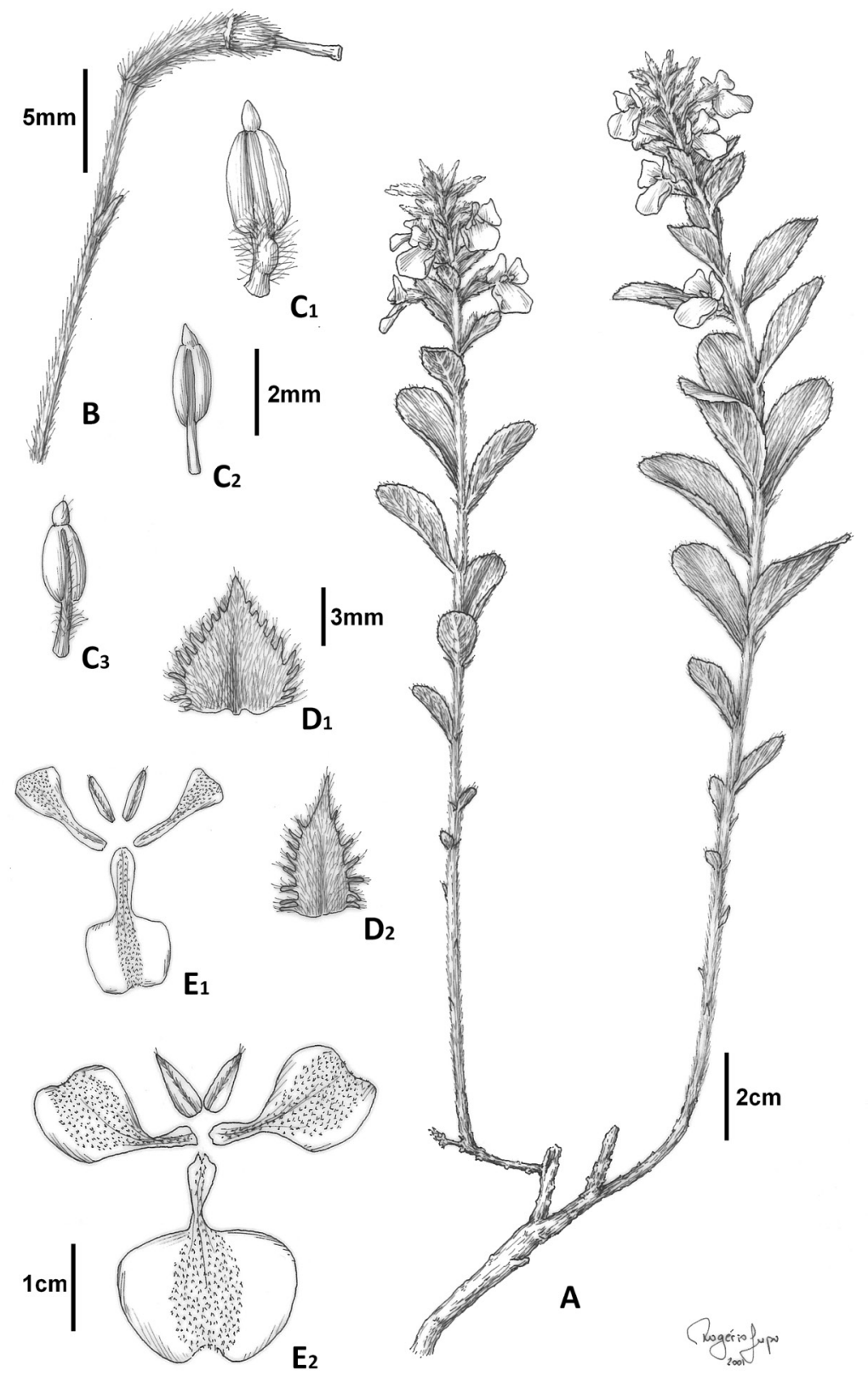

Figure 11. Pombalia velutina: $A$, habit; $B$, gynoecium on the pedicel; $C_{1}$, anterior stamen; $C_{2}$ and $C_{3}$, variation of indument and shape of connective appendage of posterior stamens; $D$, variation of size and shape of sepals; E, variation of size and shape of the corolla. Modified from Paula-Souza et al., 2011, and reproduced with the permission of the Conservatoire et Jardin botaniques de Genève. Drawn from Hatschbach 59430 (A and C $)$, Dombrowski 6627 (B), Dombrowski $676\left(C_{2}\right.$ and $\left.C_{3}\right)$, Hatschbach 37073 $\left(D_{1}\right)$, Hatschbach $45845\left(D_{2}\right)$, Hatschbach $17099\left(E_{1}\right)$ and Hatschbach $64106\left(E_{2}\right)$ by Rogério Lupo. 
entire; leaves alternate, sessile to subsessile; blade 17-33 $\times$ 6-12.5 mm, oblanceolate, elliptic to lanceolate, apex acute to obtuse or rounded, margin entire, subentire or serrate, or less frequently sharp-toothed, base acute to attenuate, tomentose to villous or woolly, hairs all stellate or frequently simple with sparse or rare stellate hairs. Flowers white, with a yellow spot at the base of the anterior petal, axillary in poorly defined racemose inflorescences or most frequently arranged in congested terminal inflorescences; pedicel 9-18(29) mm; bracteoles c. $2 \times 0.5 \mathrm{~mm}$ wide; sepals equal, $8-9.5 \times 3.5-8 \mathrm{~mm}$, lanceolate to ovate, margin fimbriate, base truncate to rounded or cordate, villous; posterior petals $6.5-9 \times 2-3.5 \mathrm{~mm}$, oblong to lanceolate; lateral petals 14-20 $\times 8.5-17 \mathrm{~mm}$, clawed or less frequently spatulate, falcate, villous; anterior petal 13-17 × 11-25 mm, including a claw 7-10 mm long, transversely oblong or less frequently subsquare, apex truncate to emarginate, smooth, villous; filaments 1-1.5 mm, connective appendages hyaline, 0.3-0.5 mm long, frequently asymmetrical, nectar glands noduliform, sometimes much reduced and inconspicuous, inserted on the filaments, villous; style 3-3.7 mm, glabrous, straight, ovary c. $2.5 \mathrm{~mm}$, villous. Capsule 9-10.5 × 6-7.5 mm, ellipsoid to ovoid; seeds c. $3 \times 2 \mathrm{~mm}$.

Etymology. The epithet refers to the dense, villous indument of the species.

Distribution and habitat. Pombalia velutina is found in grasslands and savannas from southern São Paulo to Paraná states in Brazil and adjacent areas of Paraguay, showing the southernmost distribution of this group, isolated from the other species that are typical of the core area of the Brazilian Cerrado (see Figure 3; for a more detailed discussion on its geographical distribution, see Paula-Souza et al., 2011).

Phenology. Flowering and fruiting specimens of Pombalia velutina have been collected from September to November, with a single record in December.

Conservation status. The AOO of Pombalia velutina $\left(20 \mathrm{~km}^{2}\right)$ fulfills IUCN's AOO criterion for Endangered status (EN); however, there are records of the species in conservation units, and many notes accompanying herbarium specimens refer to it as being frequent in the area. Moreover, personal observations have been of recorded populations growing in disturbed sites along roadsides. This information, combined with the species' large EOO $\left(61,264 \mathrm{~km}^{2}\right)$ suggest that it would be more accurate to assign to Pombalia velutina a conservation status of Least Concern (LC).

Selected specimens examined. BRAZIL. Paraná: Castro, na rodovia entre Castro e Itararé, Parque Florestal de Caxambú, 30 xi 1984, Mattos 26914 (HAS); Jaguariaíva, BR 151, entrada da Fazenda 3 Ledes II, a c. $1 \mathrm{~km}$ E do pedágio, 24.33310S, 49.79395W [24¹9'59.2"S, 4947'38.2"W], 26 ix 2007, Paula-Souza et al. 8736 (SPF); Palmeira, 25 x 1976, Dombrowski 6627 (MBM); Ponta Grossa, Furnas, 10 ix 1997, Cervi 6326 (MBM, NY, UPCB); Tibagi, Três Pontões, 12 x 1959, Hatschbach 6377 (ESA, HBR, MBM, US); Ventania, arredores de Ventania, 15 x 1996, Chagas e Silva \& Soares-Silva 2035 (ESA, FUEL, HUEFS, HUFU). Rio Grande do Sul: Tucunduva, 1861-62, Weir 378 (BM, F, K [K001215439, K001215440]). Santa Catarina: Abelardo Luz, 8-9 km N of Abelardo Luz, 26 $33^{\circ} \mathrm{S}, 52^{\circ} 20^{\prime} \mathrm{W}$, 
900-1000 m a.s.l., 8 xii 1964, Smith \& Klein 13868 (US). São Paulo: Itararé, 9 km de Itararé para Bom Sucesso de Itararé, beira de estrada, $24.115^{\circ} \mathrm{S}, 49.340833^{\circ} \mathrm{W}\left[24^{\circ} 11^{\prime} 12^{\prime \prime} \mathrm{S}, 49^{\circ} 16^{\prime} 22^{\prime \prime} \mathrm{W}\right], 13$ xi 2003 , Paula-Souza et al. 3645 (ESA).

This species is readily recognised by its broad and fimbriate sepals, unique among species of the Pombalia lanata complex, and the flowers usually forming congested inflorescences.

\section{Conclusions}

The Cerrado of the Brazilian Plateau is home to a strongly supported clade of Pombalia species that show specialisations in their root systems to cope with recurring disturbances such as fire and limiting edaphic conditions. The Pombalia lanata complex takes its name from its most common and widely distributed species, and comprises six taxa that frequently show overlapping morphological characteristics and distributions. Our analyses have shown that half the species of this complex, including the two new species described here, are Critically Endangered according to IUCN criteria (IUCN, 2012). Although the taxonomic boundaries of species in the Pombalia lanata complex are now better understood, multidisciplinary studies focusing on the reproductive mechanisms, ecology, and evolutionary relationships are urgently needed to guide conservation strategies.

\section{Acknowledgements}

The authors thank the curators of the herbaria consulted for making their collections available and FAPESP (São Paulo State Research Support Foundation, Brazil) and Myndel Botanica Foundation (Instituto de Botánica Darwinion, Argentina) for the grants provided. We are very grateful to our colleagues Henrique Moreira, Jair E. Q. Faria and Prof. Marco Batalha, for taking the time to document so many species of our flora and for providing beautiful images of Pombalia lanata, $P$. poaya and the new species $P$. cristalina and $P$. insignis.

\section{References}

Alonso AA, Machado SR. 2007. Morphological and developmental investigations of the underground system of Erythroxylum species from Brazilian Cerrado. Australian Journal of Botany. 55(7):749758. https://doi.org/10.1071/BT07060

Appezzato-da-Glória B, Cury G. 2011. Morpho-anatomical features of underground systems in six Asteraceae species from the Brazilian Cerrado. Anais da Academia Brasileira de Ciências. 83(3):981-992. https://doi.org/10.1590/S0001-37652011005000018

Augspurger CK. 1980. Mass-flowering of a tropical shrub (Hybanthus prunifolius): influence on pollinator attraction and movement. Evolution. 34(3):475-488. https://doi. org/10.1111/j.1558-5646.1980.tb04837.x

Aymard GC, Campbell LM, Romero-González GA. 2014. Paypayrola arenacea (Violaceae), a new species with an unusual life-form from a white sand savanna in the Amazon river basin of Venezuela. Harvard Papers in Botany. 19(2):175-184. https://doi.org/10.3100/hpib.v19iss2.2014.n2 
Bachman S, Moat J, Hill AW, de la Torre J, Scott B. 2011. Supporting Red List threat assessments with GeoCAT: Geospatial Conservation Assessment Tool. http://geocat.kew.org/ [Accessed 31 July 2018.]

Beattie AJ. 1969. The floral biology of three species of Viola. New Phytologist. 68(4):1187-1201. https://doi.org/10.1111/j.1469-8137.1969.tb06517.x

Beattie AJ. 1971. Pollination mechanisms in Viola. New Phytologist. 70(2):343-360. https://doi. org/10.1111/j.1469-8137.1971.tb02533.x

Ehleringer J. 1982. The influence of water stress and temperature on leaf pubescence development in Encelia farinosa. American Journal of Botany. 69(5):670-675. https://doi. org/10.1002/j.1537-2197.1982.tb13306.x

Ehleringer JR, Björkman O. 1978. A comparison of photosynthetic characteristics of Encelia species possessing glabrous and pubescent leaves. Plant Physiology. 62(2):185-90. https://doi. org/10.1104/pp.62.2.185

Eiten G. 1972. The Cerrado vegetation of Brazil. Botanical Review. 38(2):201-341. https://doi. org/10.1007/BF02859158

February EC, Coetsee C, Cook GD, Ratnam J, Wigley B. 2020. Physiological traits of savanna woody species - adaptations to resource availability. In: Scogings PF, Sankaran M, editors. Savanna Woody Plants and Large Herbivores. Hoboken, New Jersey: Wiley. https://doi.org/10.1002/9781119081111. ch11. pp. 311-329.

Filgueiras TS. 2002. Herbaceous plant communities. In: Oliveira PS, Marquis RJ, editors. The Cerrados of Brazil: Ecology and Natural History of a Neotropical Savanna. New York: Columbia University Press. pp. 121-139.

Freitas L, Sazima M. 2003. Floral biology and pollination mechanisms in two Viola species - from nectar to pollen flowers? Annals of Botany. 91(3):311-317. https://doi.org/10.1093/aob/mcg025

Hedberg 0. 1964. Features of Afroalpine plant ecology. Acta Phytogeogr. Suec. 49. Uppsala: Almqvist and Wiksells Boktryckeri.

Hekking WHA. 1988. Violaceae Part I - Rinorea and Rinoreocarpus. Flora Neotropica, Monograph. 46:1-207.

Inamdar JA, Gangadhara M. 2008. Studies on the trichomes of some Euphorbiaceae. Feddes Repertorium. 88(1-2):103-111. https://doi.org/10.1002/fedr.19770880105

IUCN. 2012. IUCN Red List Categories and Criteria, version 3.1, 2nd edition, iv + 32pp. Gland, Switzerland, and Cambridge: International Union for Conservation of Nature. https://portals.iucn. org/library/sites/library/files/documents/RL-2001-001-2nd.pdf [Accessed 16 August 2019.]

Karabourniotis G, Bornman JF. 2002. Penetration of UV-A, UV-B and blue light through the leaf trichome layers of two xeromorphic plants, olive and oak, measured by optical fibre microprobes. Physiologia Plantarum. 105(4):655-661. https://doi.org/10.1034/j.1399-3054.1999.105409.x

Lenthall JC, Bridgewater S, Furley PA. 1999. A phytogeographic analysis of the woody elements of the New World savannas. Edinburgh Journal of Botany. 56(2):293-305. https://doi.org/10.1017/ S0960428600001153

Marcussen T, Jakobsen KS, Danihelka J, Ballard HE, Blaxland K, Brysting AK, Oxelman B. 2012. Inferring 
species networks from gene trees in high-polyploid North American and Hawaiian violets (Viola, Violaceae). Systematic Biology. 61(1):107-126. https://doi.org/10.1093/sysbio/syr096

Marcussen T, Heier L, Brysting AK, Oxelman B, Jacobsen KS. 2014. From gene trees to a dated allopolyploid network: insights from the angiosperm genus Viola (Violaceae). Systematic Biology. 64(1):84-101. https://doi.org/10.1093/sysbio/syu071

Michener CD. 1979. Biogeography of bees. Annals of the Missouri Botanical Garden. 66(3):227-347. https://doi.org/10.2307/2398833

Miller GA. 1986. Pubescence, floral temperature and fecundity in species of Puya (Bromeliaceae) in the Ecuadorian Andes. Oecologia. 70:155-160. https://doi.org/10.1007/BF00377126

Mügge FLB, Paula-Souza J, Melo JC, Brandão MGL. 2016. Native plant species with economic value from Minas Gerais and Goiás: a discussion on the currentness of the data recovered by the French naturalist Auguste de Saint-Hilaire. Horticultura Brasileira. 34(4):455-462. https://doi.org/10.1590/ S0102-053620160402

Munzinger J, Pauly A. 2003. Mechanism of self-pollination in Hybanthus enneaspermus (L.) F. Muell. and notes on the floral biology of some Rinorea species (Violaceae) in Ivory Coast. Acta Botanica Gallica. 150(2):155-166. https://doi.org/10.1080/12538078.2003.10515416

Nunes TS, Costa JAS, Sátiro LN, Souza ER, Machado MC, Giulietti AM, Borba EL. 2006. Evidência de hibridação e introgressão em Hybanthus arenarius Ule e $H$. calceolaria (L.) Oken (Violaceae) a partir de marcadores enzimáticos e análise multivariada morfométrica. Sitientibus. Série Ciências Biológicas. 6(2):110-118.

Pacheco Filho AJS, Verola CF, Lima Verde LW, Freitas BM. 2015. Bee-flower association in the Neotropics: implications to bee conservation and plant pollination. Apidologie. 46(4):530-541. https://doi.org/10.1007/s13592-014-0344-8

Paula-Souza J. 2009. Estudos filogenéticos em Violaceae com ênfase na Tribo Violeae e revisão taxonômica dos gêneros lianescentes de Violaceae na Região Neotropical. Ph.D. dissertation, Universidade de São Paulo.

Paula-Souza J. 2018. Pombalia. In: Flora do Brasil (2020 under construction). Jardim Botânico do Rio de Janeiro. http://floradobrasil.jbrj.gov.br/reflora/floradobrasil/FB139412 [Accessed 30 July 2018.]

Paula-Souza J, Ballard HE Jr. 2014. Re-establishment of the name Pombalia, and new combinations from the polyphyletic Hybanthus (Violaceae). Phytotaxa. 183(1):1-15. https://doi.org/10.11646/ phytotaxa.183.1.1

Paula-Souza J, Pirani JR. 2014. A biogeographical overview of the "lianescent clade" of Violaceae in the Neotropical region. In: Greer F, editor. Dry Forests: Ecology, Species Diversity and Sustainable Management. New York: Nova Science Publishers. pp. 1-28.

Paula-Souza J, Souza VC. 2015. Pombalia barbata, a new species of Violaceae endemic to the Brazilian Caatinga. Phytotaxa. 218(1):91-96. https://doi.org/10.11646/phytotaxa.218.1.8

Paula-Souza J, Pirani JR, Feliciano CD. 2011. Taxonomic and geographic notes on the Hybanthus lanatus (A.St.-Hil.) Baill. complex (Violaceae). Candollea. 66(2):367-375. https://doi.org/10.15553/ c2011v662a14

Pioker-Hara FC, Drummond MS, Kleinert AMP. 2014. The influence of the loss of Brazilian savanna 
vegetation on the occurrence of stingless bees nests (Hymenoptera: Apidae: Meliponini). Sociobiology. 61(4):393-400. https://doi.org/10.13102/sociobiology.v61i4.393-400

Rosero-Lasprilla L. 1997. Biologia reprodutiva de Hybanthus atropurpureus (St. Hil.) Taub. da Reserva Municipal de Santa Genebra, Sudeste do Brasil. M.Sc. thesis, Universidade Estadual de Campinas.

Roubik DW. 1992. Ecology and Natural History of Tropical Bees. Cambridge: Cambridge University Press.

Seo M-N, Sanso A-M, Xifreda C-C. 2009. Lectotypifications in Hybanthus Jacq. (Violaceae) of the native flora of Argentina and Paraguay. Candollea. 64(2):279-281.

Thiers B. Continuously updated. Index Herbariorum: A Global Directory of Public Herbaria and Associated Staff. New York Botanical Garden's Virtual Herbarium. http://sweetgum.nybg.org/ih/ [Accessed 8 January 2020.]

Wahlert GA, Marcussen T, Paula-Souza J, Feng M, Ballard HE Jr. 2014. A phylogeny of the Violaceae (Malpighiales) inferred from plastid DNA sequences: implications for generic diversity and intrafamilial classification. Systematic Botany. 39(1):239-252. https://doi. org/10.1600/036364414X678008

Webster GL, Del-Arco-Aguilar MJ, Smith BA. 1996. Systematic distribution of foliar trichome types in Croton (Euphorbiaceae). Botanical Journal of the Linnean Society. 121(1):41-57. https://doi. org/10.1006/bojl.1996.0023

Yang Y, Körner C, Sun H. 2008. The ecological significance of pubescence in Saussurea medusa, a high-elevation Himalayan "woolly plant". Arctic, Antarctic, and Alpine Research. 40(1):250-255. https://doi.org/10.1657/1523-0430(07-009)[YANG]2.0.CO;2

\section{Appendix List of exsiccatae}

Araujo et al. 87B (3). Archer \& Gehrt 164 (3). Azevedo \& Alvarenga 769 (3).

Barbosa 872 (3). Barreto et al. 3212 (6). Batalha 3513 (2), 3693 (2), 3805 (2), 3885 (3), 3937 (2). Brochado \& Filgueiras 6 (4). Burchell 7889 (4), 8118 (3), 8152 (4). Burkart 15292 (3).

Câmara \& Filgueiras 34 (3). Cavalcanti et al. 2669 (3), CFCR 10293 (3). Cervi 6326 (6). Cesar 630 (3). Chagas e Silva \& Soares-Silva 2035 (6). Claussen 53 (3). Cordeiro et al. 444 (5).

De Haas \& Haas 551 (3). De Haas et al. 254 (4). Delprete et al. 8981 (3). Denham \& Deginani 243 (3). Dombrowski \& Scherer Neto 10090/597 (6). Dombrowski 676 (6), 6309 (6), 6627 (6), 6987 (6). Duarte, A.P. 6378 (3), 9379 (3), 9443 (4), 9976 (4). Duarte, L. 876 (3). Dusén 2768 (6), 2823 (6), 10430 (6), 15721 (6).

Faria \& Pereira 300 (3). FEEP (Araújo et al.) 292 (3). Ferreira et al. 1477 (3). Filgueiras et al. 3129 (3). Fonseca 1199 (3). Fonseca \& Alvarenga 2056 (3). Fonseca et al. 1298 (3), 1574 (3), 3671 (3). Furlan \& Cordeiro CFCR 6488 (3).

Gardner 2397-a (3), 3006 (3), 3196 (3) (K), 4091 (3). Giambiaggio s.n. SI 17125 (3). Gifford \& Fonsêca 242 (3), 243 (5). Glaziou 18871 (3), 20651 (4), 20651-a (5), 20652 (3), s.n. P04671520 (3), s.n. P04733351 (4). Guarino 810 (4). Guarino et al. 837 (3).

Harley \& Souza 10168 (3), 10337 (3). Harley et al. 10850 (3), 25455 (3). Hassler 9514 (6). Hatschbach 2796 (6), 6377 (6), 10236 (6), 12831 (6), 17099 (6), 22318 (6), 27325 (3), 37073 (6), 39133 (3), 
43375 (6), 45485 (6), 59430 (6). Hatschbach \& Kummrow 45591 (4). Hatschbach et al. 35015 (3), 69629 (3). Heleno 2765 (2). Heringer 2305 (5), 8603 (3), 8646 (4), 10703 (3), 11533 (3). Heringer et al. 2503 (5).

Irwin \& Soderstrom 6100 (3), 6285 (3), 6727 (3), 6803 (3), 6995 (3), 7573 (3). Irwin et al. 7935 (3), 8047

(3), 8384 (4), 8711 (3), 9196 (4), 9224 (3), 9226 (3), 9355 (5), 9910 (3).

Jönsson 1149a (6).

Kenj s.n. RB00785818 (3). Krapovickas \& Cristóbal 28737 (3). Krieger 7282 (6).

Lanstyak s.n. RB 56020 (3). Lasseigne 4323 (4). Lima, D.A. 61-3843 (3). Lima, L.R. et al. 190 (3).

Lindeman \& Haas 2490 (6).

Macedo 3594 (3), 3714 (4), 4821 (4). Markgraf et al. 3230 (3). Martius s.n. M (3). Mattos 26914 (6).

Mello-Barreto 9488 (3). Melo \& França s.n. (6). Mendonça et al. 654 (3), 3097 (3), 5018 (3). Mexia

5710 a (3). Moore 187 (3) (BM). Múlgura de Romero et al. 2065 (3). Munhoz et al. 736 (3).

Nakajima et al. 413 (3), 3669 (3). Netto s.n. R 79830 (4). Nissi et al. 755 (3).

Occhioni et al. s.n. UPCB 5525 (6). Olfers s.n. W0073996 (4). Oliveira \& Fonseca 2 (3).

Pabst 7112 (3). Pachêco et al. 68 (3). Pastore 2257 (3). Pastore \& Bringel 698 (4). Pastore \& Suganuma 1068 (5). Paula-Souza et al. 3645 (6), 4070 (4), 4317 (3), 4326 (1), 4531 (5), 4541 (4), 6615 (3), 6768 (1), 8215 (2), 8532 (4), 8534 (5), $8611 / 6768$ (1), 8736 (6). 8753 (3), 8774 (4), 8792 (3), 8801 (4),

$11169 / 543$ (3), 11237/611 (1), 11302/676 (5), 11311/685 (4), 11341/715 (5), 11354/728 (3). Pereira 83 (3). Pereira \& Duarte 10290/9379 (3), 10354/9443 (4). Pereira et al. 1093 (3). Pereira Neto 94 (3).

Pereira-Silva et al. 5477 (3), 12273 (4). Pfeiffer 86 (3). Pirani et al. 6612 (3). Pohl 193 (4), s.n. BM, BR (3), s.n. M (3). Pott et al. 7376 (3). Proença \& Oliveira 1562 (1).

Queiroz et al. 14974 (3), 15178 (5).

Ratter 3339 (4). Ratter \& Rocha 5014 (3). Riedel s.n. P04733350 (4). Rizzo 4383 (3), 4484 (3), 8407 (5), 8415 (5), 8474 (3). Rizzo \& Barbosa 2841 (3). Robert 547 (3), 547b (3), s.n. BM (3). Rocha 6R (3).

Romero et al. 7920 (3). Rosário et al. 15 (3).

s.col. 4091 (3), s.n. R 79823-A (6). Salles 178 (3), 204 (4). Santos et al. 11 (3), 2979 (6). Sevilha et al.

4713 (3). Silva, G.P. et al. 4408 (3), 5618 (3), 6858 (4). Silva, J.C. 739 (3). Silva, M.A. 1043 (3), 2571

(3), 4501 (3), 6154 (1), 6205A (3), 6637 (3). Silva, M.A. et al. 2398 (5), 6070 (3). Silva, R.S. s.n. HB 28626 (3). Silva \& Nicolack 731 (6). Silva \& Oliveira 2408 (3). Silva \& Pereira 913 (4). Silva \& Pinheiro 6653B (3). Silva \& Santana 6075 (3). Silva \& Souza 5363 (1). Smith 4821 (4). Smith \& Klein 13868 (6). Snak et al. 773 (3). Souza, J.P. et al. 2744 (4), 2745 (4), 2746 (1), 3540 (4), 3541 (3), 3543 (3), 3583

(3), 3584 (3). Souza, V.C. et al. 21321 (4). St.-Hilaire 589 (3), Catal. B1 no. 2080 (3), Catal. C1 no. 611

7o. (4), Catal. C1 no. 653 (4), Catal. C1 no. 864 (4).

Tozzi \& Alencar 2001-478 (3).

Ule 58 (5), 741 (3), 2752/58 (5), s.n. R 79866 (5).

Verdi et al. 7304 (5), 7311 (3), 7345 (5). Vidal \& Araujo III-504 (6). Vieira et al. 488 (3). Volpi et al. 730 (3).

Walter et al. 2676 (3), 4642 (4), 4643 (3). Weddell 2839 (4). Weir 378 (6). 